\title{
An ice sheet model of reduced complexity for paleoclimate studies
}

\author{
Basil Neff $^{1,2}$, Andreas Born ${ }^{1,2}$, and Thomas F. Stocker ${ }^{1,2}$ \\ ${ }^{1}$ Climate and Environmental Physics, Physics Institute, University of Bern, Bern, Switzerland \\ ${ }^{2}$ Oeschger Centre for Climate Change Research, Bern, Switzerland \\ Correspondence to: Andreas Born (born@ climate.unibe.ch)
}

Received: 9 July 2015 - Published in Earth Syst. Dynam. Discuss.: 11 August 2015

Revised: 1 March 2016 - Accepted: 7 March 2016 - Published: 26 April 2016

\begin{abstract}
IceBern2D is a vertically integrated ice sheet model to investigate the ice distribution on long timescales under different climatic conditions. It is forced by simulated fields of surface temperature and precipitation of the Last Glacial Maximum and present-day climate from a comprehensive climate model. This constant forcing is adjusted to changes in ice elevation. Due to its reduced complexity and computational efficiency, the model is well suited for extensive sensitivity studies and ensemble simulations on extensive temporal and spatial scales. It shows good quantitative agreement with standardized benchmarks on an artificial domain (EISMINT). Present-day and Last Glacial Maximum ice distributions in the Northern Hemisphere are also simulated with good agreement. Glacial ice volume in Eurasia is underestimated due to the lack of ice shelves in our model.

The efficiency of the model is utilized by running an ensemble of 400 simulations with perturbed model parameters and two different estimates of the climate at the Last Glacial Maximum. The sensitivity to the imposed climate boundary conditions and the positive degree-day factor $\beta$, i.e., the surface mass balance, outweighs the influence of parameters that disturb the flow of ice. This justifies the use of simplified dynamics as a means to achieve computational efficiency for simulations that cover several glacial cycles. Hysteresis simulations over 5 million years illustrate the stability of the simulated ice sheets to variations in surface air temperature.
\end{abstract}

\section{Introduction}

The understanding of the Earth's climate on timescales longer than about 100000 years (100 kyr) critically depends on the build-up and demise of continental ice sheets. Over the past several million years, their number alternated between the two that are present today on Greenland and Antarctica and four, with two additional masses of ice over both North America and Eurasia. Among other consequences, this caused sea level to drop in excess of about $130 \mathrm{~m}$ during the most recent glaciation (Austermann et al., 2013; Lambeck et al., 2014), exposing currently submerged land that allowed humans to first arrive and settle on the Americas (Dixon, 2001) and Australian continents (Forster, 2004).

Proxy records from deep sea sediments show that ice volume and temperature varied predominantly on timescales of $41 \mathrm{kyr}$ between 3 and 0.8 million years ago, and with a $100 \mathrm{kyr}$ periodicity over the past $800 \mathrm{kyr}$ (Lisiecki and
Raymo, 2005). This is somewhat inconsistent with the prevailing theory that ice sheet volume is dominated by the intensity of Northern Hemisphere summer insolation causing ice to melt (Milankovitch, 1941), because summer insolation in the Northern Hemisphere varies predominantly on the precessional timescale of $23 \mathrm{kyr}$ (Berger, 1978). Several ice sheet-climate interactions have been proposed to explain this nonlinear response of ice volume to the orbital forcing. Besides the closure of ocean pathways mentioned above, the rerouting of freshwater by ice sheets also has a profound impact on the ocean circulation and sea ice distribution (Stocker, 2013), potentially changing moisture availability for ice sheet growth (Gildor and Tziperman, 2001). Similarly, meridional water transport from the tropics to high latitudes, arguably controlled by insolation gradients instead of absolute values, has been suggested as a limiting factor of ice sheet growth (Raymo and Nisancioglu, 2003). Changes 
in topography due to the accumulation of ice alter the atmospheric circulation on local (Merz et al., 2014a, b) and hemispheric scales (Li and Battisti, 2008; Pausata et al., 2011; Merz et al., 2013). As ice sheets are usually brighter than the surface they replace, they impact the planetary radiation balance in the short-wavelength part of the spectrum (Cess et al., 1991). The long-wavelength radiation balance also changes with the growth of ice sheets as the concentration of atmospheric greenhouse gases closely follows global ice sheet volume (Loulergue et al., 2008; Lüthi et al., 2008; Schilt et al., 2010). Probable causes include changes in the ocean circulation (Archer et al., 2000; Fischer et al., 2010) and terrestrial peatlands (Xu-Ri and Prentice, 2008; Spahni et al., 2013). Lastly, ice sheets interact with the lithosphere, sinking into their beds when growing and thereby shifting their surface mass balance toward negative values (Oerlemans, 1981b).

Although these basic components are easily understood at their individual level, the full picture is very complex; therefore, comprehensive numerical modeling is necessary to quantify the underlying physical processes. The often prohibitive cost to run climate models over periods of several millennia has limited such attempts to use of either somewhat arbitrary methods to reduce simulation time (e.g., Herrington and Poulsen, 2011; Abe-Ouchi et al., 2013; Heinemann et al., 2014) or climate models of reduced complexity (Gallée et al., 1992; Smith et al., 2003; Charbit et al., 2007; Bonelli et al., 2009; Robinson et al., 2011; Ganopolski and Calov, 2011; Stap et al., 2014). However, in spite of their focus on numerical efficiency, the ice sheet models used in some of the latter studies rival their climate model counterparts in complexity and computational cost, which is not justified for all applications. The use of complex ice sheet and ice shelf dynamics consumes resources that in specific cases would be better allocated for a more detailed description of the ice sheetclimate interface or a probabilistic analysis. Importantly, the nonlinearities that might shape the response of global ice volume to insolation as outlined above do generally not postulate a major role for the complexity of the three-dimensional flow of ice.

In this study, we present a vertically integrated ice sheet model (IceBern2D) that is efficient enough to add only a small computational overhead even to the fastest coarseresolution climate models. This enables simulations spanning several glacial cycles and exploration of nonlinearities in the ice sheet-climate system. Similar models have successfully been employed in the past on a hemispheric scale (Neeman et al., 1988; Verbitsky and Oglesby, 1992) and for regional applications (Oerlemans, 1981a; Siegert and Marsiat, 2001; Plummer and Phillips, 2003; Näslund et al., 2003). However, vertically integrated ice sheet models have mostly fallen into disuse in recent years in favor of more demanding three-dimensional models. The dynamics of the IceBern2D model are similar to early one-dimensional models (Oerlemans, 1981b, 1982) but are calculated on a two-dimensional grid. This type of model has been found to produce results similar to three-dimensional thermomechanical models (Calov and Marsiat, 1998).

The IceBern2D model is described in detail in Sect. 2. It is found to perform well in idealized experiments (EISMINT; Huybrechts et al., 1996, Sect. 3) as well as in simulations under continuous Last Glacial Maximum (LGM) and preindustrial climate forcing (Sect. 4). We take advantage of the efficiency of the model by using a large ensemble of simulations to estimate the best combination of model parameters (Sect. 4.1). The multi-stability of the Northern Hemisphere ice sheets is investigated in idealized experiments of 5 million years duration (Sect. 4.3). These long simulations with multiple starting conditions illustrate the high numerical performance as one of the major features of the model. We summarize and discuss these results in Sect. 5 and provide an outlook on future directions in Sect. 6.

\section{Model formulation}

The IceBern2D model is designed to investigate the twodimensional flow of ice and its distribution in the Northern Hemisphere under different climatic conditions. Therefore, the physical basis of the model is reduced to the most important processes. It is based on the conservation of mass and simulates the flow of ice in two dimensions, the vertical flow of ice is not simulated explicitly. The forcing of the model is deliberately chosen to only include precipitation and temperature in order to allow for a wide range of usage scenarios with coupled and uncoupled climate models, observational data, and possibly climate proxy reconstructions.

The model is based on different physical and empirical constants. Empirical constants are primarily determined from present-day conditions and may vary under different climates and geographical locations. Therefore, these values are used as tuning parameters for different simulations in a common ensemble and marked in Table 1.

The IceBern2D model is discretized on a $\mathrm{C}$ grid (Arakawa and Lamb, 1977) (Fig. 1). The staggered $C$ grid is characterized by a combination of calculated values at the center and the border of the grid. This combination yields the most stable results in our simulations.

\subsection{Ice dynamics}

The basis of the model is formed by the conservation of ice volume in time (Oerlemans, 1981b; Huybrechts et al., 1996). The rate of change in ice thickness $h$ with time is formulated as

$$
\frac{\partial h}{\partial t}=\nabla \cdot D(\nabla Z)+M
$$

where $M$ represents the annual net surface mass balance, which is described in Sect. 2.3. The flow of ice takes the form of a diffusion with the nonlinear diffusivity $D$ detailed 
Table 1. Values of constants used in the ice model. The parameters that are used to tune the model are highlighted with a checkmark and therefore not constant between different members in the ensemble (Table 3). The values for the reference parameters set are given here.

\begin{tabular}{llc}
\hline Value & Quantity & Ensemble \\
\hline$n=3$ & Flow-law exponent & \\
$A=10^{\mathrm{a}}$ & \\
$E=16 \mathrm{~Pa}^{-3} \mathrm{yr}^{-1}$ & Flow-law parameter & \\
$T_{\mathrm{acc}}=2^{\circ} \mathrm{C}$ & Flow enhancement parameter & $\checkmark$ \\
$\beta=6 \mathrm{~mm} \mathrm{PDD}^{-1}$ & Accumulation temperature & $\checkmark$ \\
$g=9.81 \mathrm{~m} \mathrm{~s}^{-2}$ & Melting factor & $\checkmark$ \\
$\rho=910 \mathrm{~kg} \mathrm{~m}^{-3}$ & Gravitational acceleration & \\
$\tau_{\text {br }}=3000 \mathrm{yr}$ & Ice density & $\checkmark$ \\
$A_{\text {ocean }}=3.6 \times 10^{14} \mathrm{~m}^{2}$ & Relaxation time for bedrock sinking & \\
$\mathrm{SL}_{\text {offset }}=7.36 \mathrm{~m}$ & Ocean surface & \\
$\Gamma=6.5 \mathrm{~K} \mathrm{~km}^{-1}$ & Tea level offset for an ice-free Greenland & \\
$\lambda_{\mathrm{p}}=\ln (2) \mathrm{km}^{-1}$ & Precipitation lapse rate & \\
\hline
\end{tabular}

${ }^{\mathrm{a}}$ Huybrechts et al. (1996); ${ }^{\mathrm{b}}$ Bamber et al. (2013); ${ }^{\mathrm{c}}$ Budd and Smith (1979)

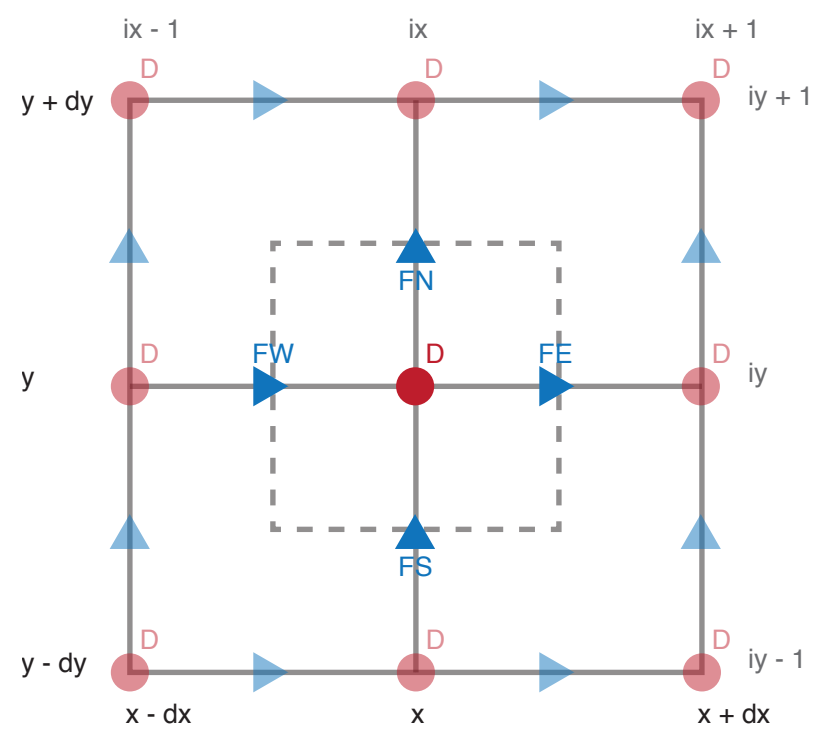

Figure 1. Schematic representation of the model grid. Ice thickness $h$, bedrock elevation $b$ and diffusivity $D$ are calculated on regular grid points (ix, iy). Halfway between these points, the lateral flux (FN, FS, FW, FE) of ice is calculated on staggered grid points.

below and the gradient of the ice surface elevation $Z$ above sea level. $Z$ is the sum of bedrock elevation $B$ and ice thickness $h$. The vector differential operator $(\nabla)$ is defined for the two lateral dimensions.

The diffusivity $D$ is calculated from Glen's flow law (Glen, 1955) by assuming that longitudinal stresses can safely be neglected over the much higher shearing of horizontal planes. This is the so-called "shallow-ice approximation" (Hutter, 1983) that can be justified by the fact that the grid spacing is at least a factor of 10 greater than the vertical extension of the ice. This approximation is not valid for ice shelves, which are therefore not included in this model. To obtain the ice volume flow, the flow law is integrated over the full height (Huybrechts et al., 1996) such that

$D=\frac{2 E A\left(\rho_{\text {ice }} g\right)^{n}}{n+2} h^{n+2}\left[\left(\frac{\partial Z}{\partial x}\right)^{2}+\left(\frac{\partial Z}{\partial y}\right)^{2}\right]^{\frac{(n-1)}{2}}$,

where $A$ and $n$ are two empirical parameters determined from a power-law fit of strain rate and effective shear stress (Table 1). A generally depends on the temperature of the ice, which cannot be calculated here due to the missing vertical coordinate. We therefore adopt a constant value. The plasticity and hence its flow velocity can be modified by an empirical enhancement parameter $E$, which is commonly used to parameterize the softer, impurity-rich glacial ice (Fisher and Koerner, 1986). $\rho_{\text {ice }}$ and $g$ are the density of ice and the gravitational acceleration, respectively (Table 1).

The discretization on the model grid is as follows. The ice diffusivity $D$, Eq. (2), is calculated on the regular model grid, for which the gradients in surface elevation $\frac{\partial Z}{\partial x}$ and $\frac{\partial Z}{\partial y}$ are calculated from centered differences. Thereafter, the flow of ice is calculated according to Eq. (1) on the staggered grid points (FN, FS, FW, FE in Fig. 1). The diffusivity $D$ is interpolated on these points. Lastly, the four ice fluxes surrounding one regular grid box are used to determine the ice thickness on the regular grid for the next time step of 1 year.

\subsection{Bedrock relaxation}

Thick ice sheets exert a substantial mass load on the underlying bedrock. This leads in equilibrium to an isostatic sinking of the bedrock by about one-third, corresponding to the inverse ratio of rock and ice density $\frac{\rho_{\text {rock }}}{\rho_{\text {ice }}} \approx 3$, the hydrostatic equilibrium (Le Meur and Huybrechts, 1996). This is an important mechanism because it influences the melt- 
Table 2. List of CCSM4 simulations of preindustrial (PI) and Last Glacial Maximum (LGM) climates (Hofer et al., 2012; Merz et al., 2013) which are used as climate forcing in the ice model. Orbital parameters are calculated according to Berger (1978). Solar forcing is expressed as total solar irradiance (TSI). The LGM simulation uses the ICE-5G topography reconstruction (Peltier, 2004). All simulations have a time resolution of 1 day and a spatial resolution of $0.9^{\circ} \times 1.25^{\circ}$ which is bilinearly interpolated to the ice model resolution.

\begin{tabular}{llllllll}
\hline Simulation & Orbital parameters & SST/sea ice & $\mathrm{CO}_{2}[\mathrm{ppm}]$ & $\mathrm{CH}_{4}[\mathrm{ppb}]$ & $\mathrm{N}_{2} \mathrm{O}[\mathrm{ppb}]$ & $\mathrm{TSI}\left[\mathrm{W} \mathrm{m}^{-2}\right]$ & Ice sheets/topography \\
\hline PD & present & $\mathrm{PD}$ & 354 & 1694 & 310 & 1361.8 & present \\
PI & present & PI & 280 & 760 & 270 & 1360.9 & present \\
LGM & $21 \mathrm{ka}$ & $21 \mathrm{ka}$ & 185 & 350 & 200 & 1360.9 & $21 \mathrm{ka}$ \\
\hline
\end{tabular}

ing of the ice. When the bedrock deforms under the loading of the ice, the top of the ice sheet sinks to a lower and warmer position. This temperature increase promotes melting and thereby feeds back to the surface mass balance.

A simple yet effective formulation of the bedrock adjustment is the exponential sinking toward its hydrostatic equilibrium (Oerlemans, 1981b):

$$
\frac{\partial B}{\partial t}=-\tau_{\mathrm{br}}^{-1}\left(\frac{\rho_{\text {rock }}}{\rho_{\text {ice }}} h+B-B_{0}\right) \text {. }
$$

$B$ is the bedrock elevation, $B_{0}$ is the elevation of the bedrock without ice load, and $h$ represents the ice thickness. The relaxation time $\tau_{\text {br }}$ represents a characteristic time it takes to restore equilibrium. A common value for $\tau_{\mathrm{br}}$ is 3000 years (Huybrechts, 2002), but the value may vary locally. Therefore $\tau_{\mathrm{br}}$ is used as a tuning parameter here (Table 3). Equation (3) is a simplified representation of mass flow in the Earth's upper mantle. It only affects the local grid point and no surrounding fields which is considered sufficient for the purpose of an ice sheet model of reduced complexity. This is the "local lithosphere, relaxed asthenosphere" (LLRA) model (e.g., Le Meur and Huybrechts, 1996)

For the elevation of the bedrock without ice load $\left(B_{0}\right)$, ETOPO1 data are used (Amante and Eakins, 2009). ETOPO1 has a resolution of 1 arcmin and distinguishes between bedrock and ice surface. For our application the resolution is linearly interpolated to a stereographic grid of $40 \mathrm{~km}$. It is assumed that bedrock deformation in Greenland is in close isostatic equilibrium with the ice sheet under present-day conditions. Thus, $B_{0}$ is estimated by adding one-third of the ice thickness to the bedrock elevation which corresponds to the mentioned inverse ratio of rock and ice density. This isostatic correction is applied to compensate for an ice-free Northern Hemisphere at the beginning of the simulation. In the model domain and at $40 \mathrm{~km}$ resolution, this adjustment of the bedrock only affects Greenland.

\subsection{Surface mass balance}

The surface mass balance $M$, i.e., the accumulation minus the ablation, determines where the ice sheet gains or loses mass and thereby drives the flow of ice, i.e., Eq. (1). $M$ is calculated from daily surface air temperature and precipitation fields. These data are obtained from simulations with the atmosphere component of the Community Climate System Model version 4 (CCSM4) (Gent et al., 2011; Neale et al., 2013). We employ simulations of both preindustrial (PI) and glacial (LGM) climates (Table 2, Fig. 2), which have been analyzed and validated earlier by Hofer et al. (2012) and Merz et al. (2013). The lower boundary conditions for the sea surface are derived from fully coupled simulations with the preceding model version, CCSM3, as outlined in detail in the original publications. Each CCSM4 simulation ran for 33 years. Climatological daily fields of surface air temperature and total precipitation of the last 30 years of the simulations are extracted to force the ice sheet model. The spatial resolution is $0.9^{\circ} \times 1.25^{\circ}$.

All simulated climate variables are referenced to the continental surface in the relatively coarse grid of the climate model. This does not concur with the more finely resolved topography of the ice sheet model, in particular since the growth of ice entails considerable changes in the surface elevation. Thus, after a bilinear interpolation from the climate model to the ice sheet model grid, the climatological fields of surface air temperature are corrected for altitude with a constant lapse rate $\Gamma=-6.5 \times 10^{-3} \mathrm{Km}^{-1}$ (Table 1):

$T_{\mathrm{ISM}}(t)=T_{\mathrm{GCM}}+\Gamma \cdot\left(Z_{\mathrm{ISM}}(t)-Z_{\mathrm{GCM}}\right)$,

where $Z_{\mathrm{GCM}}$ is the elevation of the interpolated climate model grid and $Z_{\mathrm{ISM}}(t)$ is the time-dependent elevation of the ice sheet model surface; the same applies for $T_{\mathrm{GCM}}$ and $T_{\text {ISM }}(t)$. This correction is applied throughout the ice sheet model simulation to account for changes in ice surface topography.

Precipitation is corrected with a height-desertification effect. Where the ice surface $Z_{\text {ISM }}$ exceeds an elevation of $Z_{0}=2000 \mathrm{~m}$, the precipitation is halved every $1000 \mathrm{~m}$ (Budd and Smith, 1979). However, where the elevation of the climate model input already accounts for a surface that is higher than $2000 \mathrm{~m}$, the desertification only starts at this higher reference point. This is important because the high elevation in the climate model already implies a decrease in precipitation that must not be compounded with an additional reduction. Thus, the precipitation rate $P_{\mathrm{ISM}}(\mathrm{t})$ at the evolving height of the ice sheet $Z_{\text {ISM }}(t)$ is derived from the precipitation of the 

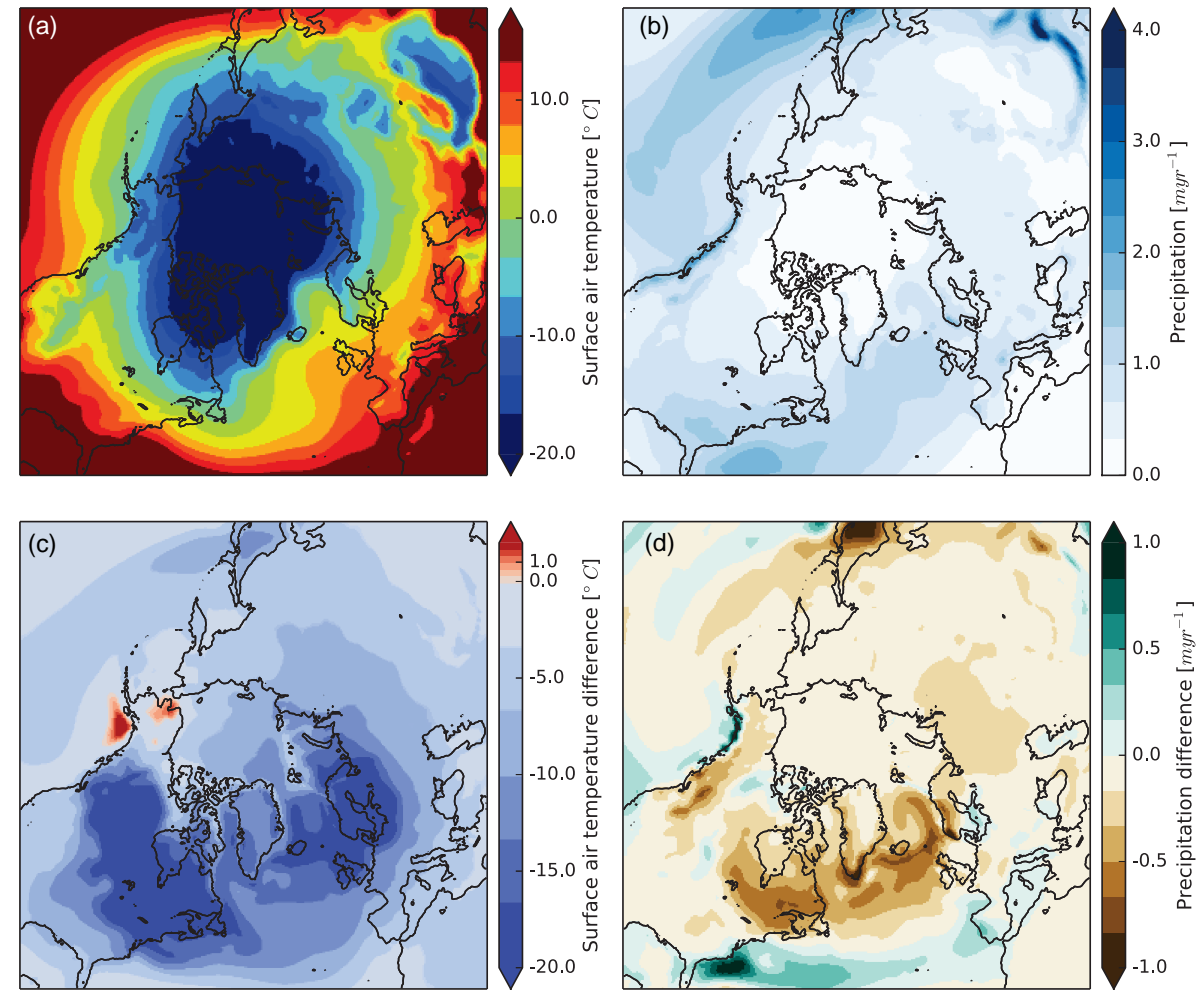

Figure 2. Annual mean surface air temperature (a) and total annual precipitation (b) of the preindustrial (PI) climate forcing from CCSM4. The anomalies of the LGM climate forcing with respect to PI (LGM - PI) are shown in (c) and (d). No correction for surface elevation or temperature bias has been applied here.

general circulation model $(\mathrm{GCM}) P_{\mathrm{GCM}}$ as follows:

$$
\begin{aligned}
& P_{\mathrm{ISM}}(t)=P_{\mathrm{GCM}} \cdot \exp \left(-\lambda_{\mathrm{p}}\left(\max \left(Z_{\mathrm{ISM}}(t), Z_{0}\right)\right.\right. \\
& \left.\left.-\max \left(Z_{\mathrm{GCM}}, Z_{0}\right)\right)\right),
\end{aligned}
$$

with $\lambda_{\mathrm{p}}=\ln (2) / 1000 \mathrm{~m}$ (Table 1). Note that this formulation may lead to an amplification of precipitation at grid points that have a lower elevation in the ice sheet model than in the GCM. This is important for the central part of North America at the beginning of the ice sheet simulations that are forced with a LGM climate from a GCM. Here, the GCM provides a very dry climate due to the presence of the North American ice sheet (Fig. 2d). This dry climate together with relatively high temperatures due to the still low elevation in the ice sheet model effectively inhibits the accumulation of ice in this region. While an amplification of precipitation is acceptable in this limited framework, the large difference in elevation together with the doubling of the precipitation every $1000 \mathrm{~m}$ (for a negative difference in surface elevation) could potentially lead to extremely high precipitation rates, lacking physical justification. However, this case is avoided by also referencing the amplification of precipitation to $Z_{0}=2000 \mathrm{~m}$, in accord with previous formulations (Vizcaino et al., 2008).

These corrections of precipitation are fundamentally different from experiments that use a glacial index to interpo- late between glaciated and ice-free climate states (Marshall et al., 2000; Zweck and Huybrechts, 2005). There, the heightdesertification effect is assumed to be already included in the climate simulations. It has also been proposed to estimate precipitation rates from fields of surface air temperature and mid-troposphere wind fields, making assumptions on how their interaction with changes in ice sheet topography influences moisture availability and orographic uplifting (Roe and Lindzen, 2001; Roe, 2002; de Boer et al., 2013). While this approach takes into account the potentially highly important localized precipitation near the slopes of the ice sheet (Merz et al., 2014b), it is arguably better suited for periods for which direct climate simulations are not available.

Comparison of the present-day simulation of CCSM4 with reanalyzed data from ERA-Interim (Dee et al., 2011) reveals considerable temperature biases. The CCSM3 simulation which is used as ocean forcing for the CCSM4 simulations overestimates the amount of sea ice in the Northern Hemisphere (Collins et al., 2006), causing too cold temperatures in these areas (Fig. 3). The anomalies range from -12.5 to $+5.5^{\circ} \mathrm{C}$ with an overall average of $-3.0^{\circ} \mathrm{C}$.

To remove the bias of the present-day CCSM4 climate, temperature of the surface of the CCSM4 simulations is subtracted from the daily temperature fields after interpolation to the ice sheet grid but before the lapse rate correction. 


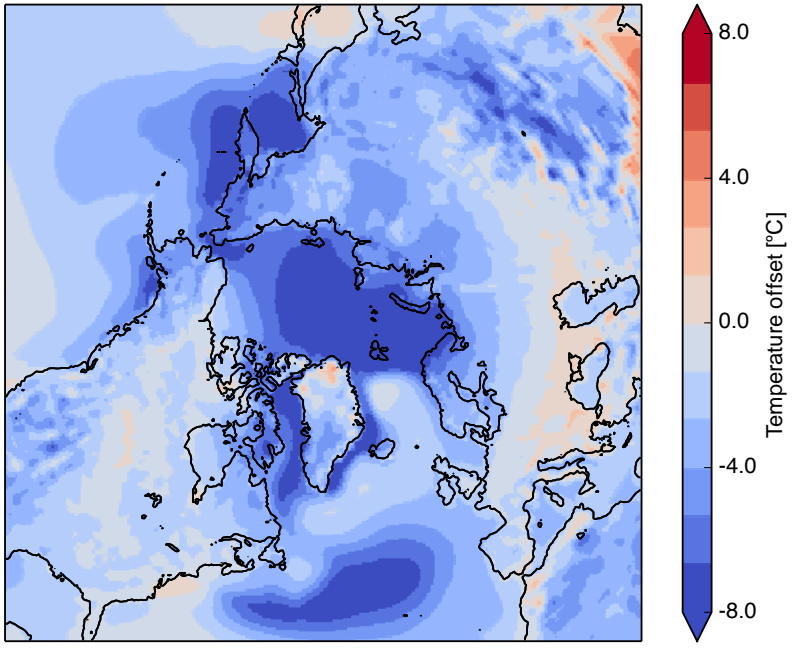

Figure 3. Difference between the CCSM4 PD and ERA-Interim temperature (CCSM4 PD - ERA-Interim) interpolated onto the ice sheet model grid. A general cold bias with an average of $-3.0^{\circ} \mathrm{C}$ is observed over the full domain. Largest offsets are found in regions with excessive sea ice in the model as well as in the path of the North Atlantic Current.

The influence of this correction is investigated by forcing the ice sheet model with both the corrected $\left(\mathrm{LGM}_{\mathrm{bs}}\right.$, where bs stands for bias subtracted) and uncorrected $\left(\mathrm{LGM}_{\mathrm{uc}}\right.$, where uc stands for uncorrected) surface climate fields. The precipitation is not altered in any simulation concerning this temperature bias. But note that the ratio of solid to liquid precipitation of the accumulation is affected by the temperature change.

After the spatial interpolation and correction is performed on the entire daily climatology of the climate forcing fields, accumulation and ablation are calculated for 1 full year to obtain the annual surface mass balance $M$. This is in accord with the duration of the time step of 1 year for the flow of ice. Accumulation is the cumulative daily precipitation on days with an average temperature below $0{ }^{\circ} \mathrm{C}$, integrated over 1 year. However, the use of daily averages does not account for potentially lower temperatures during the night that may be below freezing. Also, precipitation at temperatures above the melting point might refreeze upon contact with the cold snow surface. Thus, the sensitivity of the accumulation temperature $T_{\text {acc }}$ is tested and used to tune the model.

Melting of the ice is parameterized with the positive degree-day method (Reeh, 1991). For each grid point, daily average temperatures above $0^{\circ} \mathrm{C}$ are integrated over 1 year to obtain the positive degree days (PDD) as a simplified measure of the energy available for melting. This number is then multiplied by the melting parameter $\beta$ to calculate the mass loss. $\beta$ is an empirical constant that accounts for the effect of the local climate and the surface radiation balance. Thus, it is known to largely vary with changing surface conditions, including the density of the surface snow or ice, the presence of meltwater, and other effects on the local albedo (Braithwaite, 1995; Charbit et al., 2013). To partially account for these effects, many studies employ two individual melting parameters for snow and bare ice (Huybrechts and T'siobbel, 1995; Huybrechts and de Wolde, 1999). The extent and volume of simulated ice sheets is very sensitive to the choice of melting parameters (e.g., Ritz et al., 1997). However, since the present model emphasizes numerical efficiency and a minimum of external forcing data to be supplied, a representation of the snow layer is not available. Therefore, only one melting parameter is used for ice. This reduces the degrees of freedom to tune the model to observed or reconstructed distributions of ice, but it also reduces the risk of overfitting because the positive degree-day parameters are only weakly constrained by physics and can be chosen over a wide range of possible values. As with the accumulation temperature, the sensitivity of the ice sheet to $\beta$ is also tested and used for tuning purposes (Table 3).

\subsection{Model domain}

The domain of the model is limited to the Northern Hemisphere, where approximately $80 \%$ of the changes in ice volume during the LGM took place (Clark and Mix, 2002). A polar azimuthal projection is used as a grid base. The lateral grid is identical to the one of SICOPOLIS (Greve, 1997; Born et al., 2010).

The spatial resolution is $40 \mathrm{~km} \times 40 \mathrm{~km}$. Each grid cell has exactly one vertical layer which stores all information such as ice thickness, accumulation, and ablation. An ice mask is introduced to reduce cost-intensive ice flux calculations to grid cells with ice instead of the entire model domain. The temporal resolution is 1 year.

The surface mass balance of the Himalayas is not well represented in the current model version. The simplified ablation scheme does not explicitly account for melting by shortwave radiation at subzero temperatures and large intra-day and intra-seasonal variations in both accumulation and melting. Both effects are more important at the subtropical latitude of the Himalayas than further north, where glacier growth and decay are confined to two individual seasons. Thus, in the Himalayas, the approach used here leads to an unrealistically high accumulation rate, which destabilizes the model. For this reason, the accumulation in this region is set to zero.

\subsection{Sea level}

The changing sea level during the simulations has a large influence on the ice flow, since some shallow bays fall dry and provide the possibility for the ice to cover new areas, for example the Baltic Sea or the Grand Banks of Newfoundland.

All simulations start without any ice in the Northern Hemisphere, which leads to an offset in sea level compared to today's situation. This offset is the equivalent total ice volume of the Greenland ice sheet of $7.36 \mathrm{~m}$ (Table 1) (Bamber et al., 

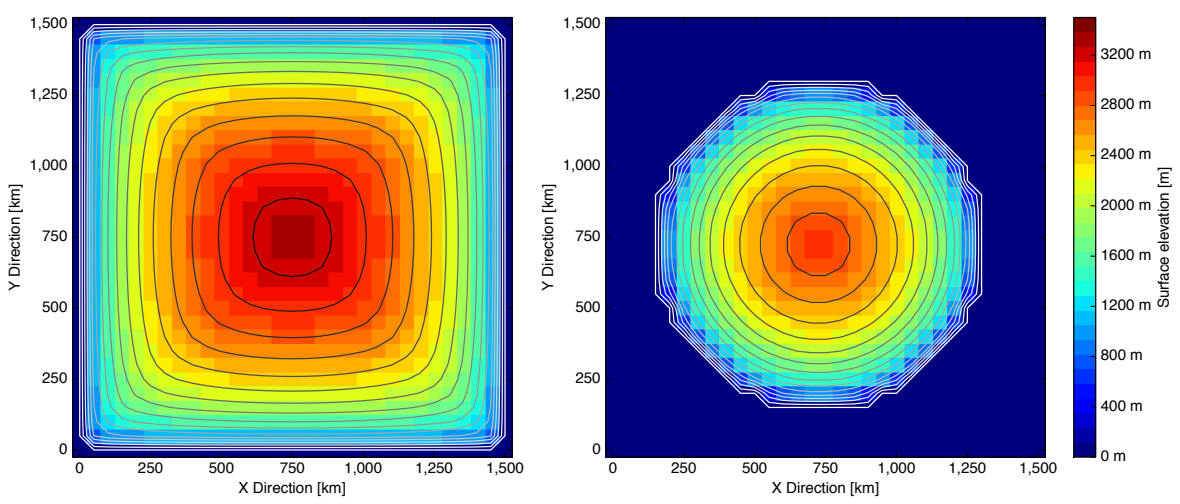

Figure 4. Results of the EISMINT fixed $_{\text {(left) and EISMINT }}$ freemargin (right) comparison at a steady state around 200000 simulated years. Both images show ice surface elevation of the IceBern2D model with contour lines of $200 \mathrm{~m}$ equidistance. The EISMINT fixed $_{\text {id identical }}$ with the test from Huybrechts et al. (1996); the peak is in the center of the grid at an elevation of $3342.6 \mathrm{~m}$. EISMINT $_{\text {freemargin }}$ has a deviation of $1 \%$ from Huybrechts et al. (1996); the peak in the center is at $2925 \mathrm{~m}$.

Table 3. Four tuning parameters with their used values. All possible combinations of parameter values result in 200 experiments which are run with two different versions of LGM climate forcing.

\begin{tabular}{llll}
\hline Name & Abbreviation & Unit & Values \\
\hline Melting parameter & $\beta$ & $\mathrm{mm} \mathrm{PDD}^{-1}$ & $5 ; 6 ; 7 ; 8 ; 9$ \\
Flow enhancement parameter & $E$ & $\%$ & $75 ; 100 ; 125 ; 150$ \\
Accumulation temperature & $T_{\mathrm{acc}}$ & ${ }^{\circ} \mathrm{C}$ & $0 ; 1 ; 2 ; 3 ; 4$ \\
Bedrock relaxation time & $\tau_{\mathrm{br}}$ & $\mathrm{yr}$ & $3000 ; 6000$ \\
\hline
\end{tabular}

2013). The change in the global mean sea level is retrieved by dividing the water equivalent of the total ice volume by the ocean area of $3.625 \times 10^{14} \mathrm{~m}^{2}$. The global sea level and corresponding land mask is a function of the simulated ice volume and adjusted every 50 years for computational efficiency. The initial positive offset of $7.36 \mathrm{~m}$ is added to all sea level calculations; therefore an ice-free Northern Hemisphere is not equal to $0 \mathrm{~m}$ sea level equivalent (ms.l.e.).

Ice shelves are not simulated. Ice is assumed to calve into the ocean upon contact with the shoreline, approximated by setting the ice thickness to zero at these points. This may result in less ice in the coastal areas if neglecting the buttressing effect of ice shelves (Dupont and Alley, 2005). However, to avoid overly rapid ice loss due to rising sea level, already existing ice is allowed to persist unless it starts to float. If the existing ice column with a density of $910 \mathrm{~kg} \mathrm{~m}^{-3}$ is able to displace the water column between the bedrock and sea level (i.e., the hydrostatic equilibrium is not yet reached), the ice is still treated as grounded and the grid point is equivalent to land. As soon as the mass of the water column exceeds the ice mass, all ice is removed and the grid cell is converted to a water cell.

\section{Idealized simulations using EISMINT and conservation of mass}

In order to test the present model formulation, we perform a series of benchmark experiments defined by the European Ice Sheet Modelling INiTiative (EISMINT) (Huybrechts et al., 1996). To validate our model and their results, both the fixed-margin (EISMINT fixed $_{\text {}}$ ) and moving-margin (EISMINT freemargin $_{\text {}}$ experiments are carried out.

EISMINT $_{\text {fixed }}$ uses a flat bed without relaxation. It prescribes a constant surface mass balance of $0.3 \mathrm{~m} \mathrm{yr}^{-1}$ in the entire domain. The shape of the simulated ice sheet is symmetric, ruling out inconsistencies in the grid configuration (Fig. 4, left). Our experiment EISMINT fixed is indistinguishable from the reference (Huybrechts et al., 1996). Both peaks in the center of the area are $3342.6 \mathrm{~m}$ above the bed.

The second benchmark EISMINT freemargin $_{\text {also uses a flat }}$ rigid bed. Here, the surface mass balance linearly decreases from the center of the grid toward the boundaries. This pattern is point-symmetric around the central point so that the surface mass balance function resembles an upright cone. Thus, the IceBern2D simulation is also symmetric with respect to the center of the model domain (Fig. 4, right). Again, we find very close agreement with the results of Huybrechts et al. (1996), with a deviation of less than $1 \%$ in the elevation of the central peak. 

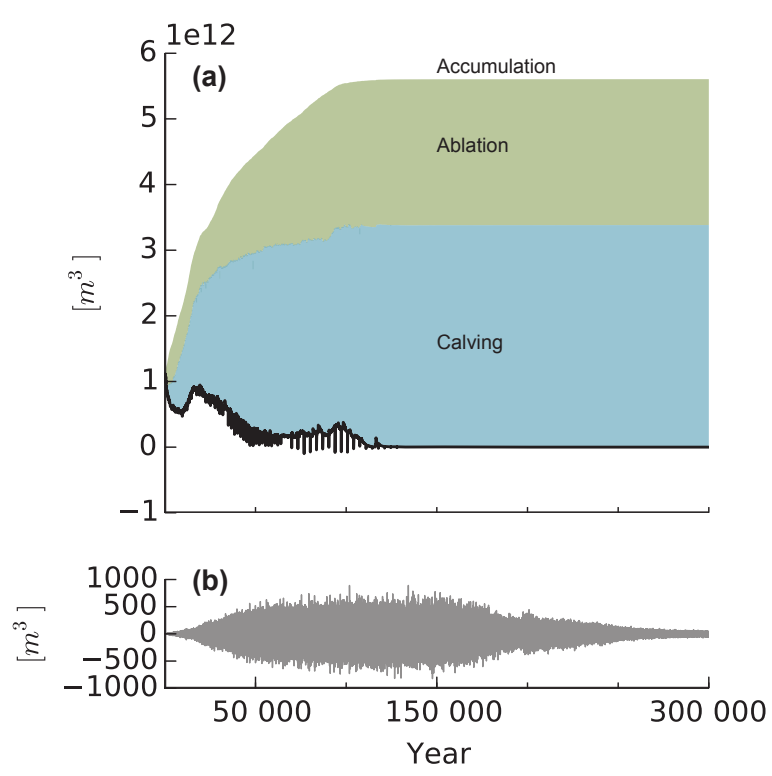

Figure 5. (a) Integrated mass balance as a function of time for the Northern Hemisphere domain. The upper panel shows the total accumulation integrated over the entire domain (upper boundary of colored area) as well as the effect of ablation (green) and calving (blue). The lower boundary of the colored area is the sum of all three components, i.e., the estimate of the net integrated mass balance. The solid black line represents net changes in total ice volume as diagnosed from the model directly. (b) Difference between the sum of contributions and the true change in ice volume in the model, which is at least 10 orders of magnitude smaller than the calculated fluxes.

The idealized simulations confirm the validity of the formulation and implementation of the IceBern2D model. However, since they significantly differ in their complexity from the intended application in the Northern Hemisphere domain, additional simulations are necessary to ensure that mass is conserved. One simulation has been carried out that records all relevant fluxes of volume in the model at every time step (Fig. 5). It includes the full complexity of the model with the calculation of the surface mass balance, ice loss at the coasts (calving), interactive bedrock, and changes in sea level. While the individual components of the mass balance are fluxes of the order of $10^{12} \mathrm{~m}^{3} \mathrm{yr}^{-1}$, the difference between the sum of these and the change in volume as calculated by the model is less than $1000 \mathrm{~m}^{3} \mathrm{yr}^{-1}$ at all times during the simulation. In an ideal case this difference should be zero, but small errors due to truncation at machine precision and numerically imprecise compiler optimizations to achieve a minimal computational time add up to an expected and irreducible mismatch. Consistent with this, the mismatch grows with the size of the ice volume at the beginning of the simulation. After about 140000 years, the mass balance reaches an equilibrium but the numerical error remains at the same amplitude until 200000 years into the simulation. This suggests that internal adjustments in the ice sheet continue, for example changes at the coastal margins that propagate as waves toward other parts of the ice sheet, which in turn could cause subsequent responses. Adjustments in the sea level as a function of the captured ice on land are only calculated every 50 years. A dropping sea level pauses the calving in affected areas for some time steps until the ice reaches the coast again. Calving is relatively high as soon as the water is reached because additional ice could be accumulated in these time steps, but a local equilibrium is reinstated shortly after. This is observed in the intermittent peaks in the ice flux. Importantly, none of these effects has a systematic influence on the model error, which proves that the model conserves mass even with radical and potentially unrealistically fast adjustments during its spin-up from ice-free conditions. Moreover, over the course of the entire simulation, the integrated error stays centered around zero, so that the long-term average is less than $1 \mathrm{~L}$ per year for the entire domain in the Northern Hemisphere.

\section{Northern Hemisphere ice volume in preindustrial and glacial climates}

\subsection{Last Glacial Maximum climate forcing, model tuning}

The sensitivity of the IceBern2D model to four empirical model parameters is investigated by varying their values within their respective ranges of uncertainty (Table 3 ). This method is commonly used to find an optimal set of parameters for an ice sheet model or to explore the uncertainty of physically reasonable parameter choices (Robinson et al., 2011; Born and Nisancioglu, 2012; Stone et al., 2013). There are two parameters that change the surface mass balance: the melting parameter $\beta$ and the accumulation temperature $T_{\text {acc }}$. The other two influence the ice flow. The flow enhancement parameter $E$ linearly modifies the flow-law parameter $A$ (Eq. 2). $\tau_{\text {br }}$ determines the relaxation time of the bedrock, which influences the ice flow. If the bedrock stays longer at its initial elevation, the elevation gradient $\nabla Z$ is higher (Eq. 2). The bedrock relaxation $\tau_{\mathrm{br}}$ also has an indirect influence on the surface mass balance. The elevation and therefore the temperature decreases at the surface when the elevation yields under the ice. A shorter relaxation time leads to a decrease in the surface mass balance. All possible parameter perturbations amount to a total of 200 combinations. Each simulation is forced with the two versions of LGM forcing outlined above.

The spread of the ice volume in meters of sea level equivalent (ms.l.e.) depends significantly on the climate forcing. For the climate forcing without temperature bias correction $\left(\mathrm{LGM}_{\mathrm{uc}}\right)$, the spread of the ice volume is between -270 and $-65 \mathrm{~m}$ s.l.e., while the spread for the bias corrected climate forcing $\left(\mathrm{LGM}_{\mathrm{bs}}\right)$ is much smaller, between -130 and $-65 \mathrm{~m}$ (Fig. 7, lower part). 


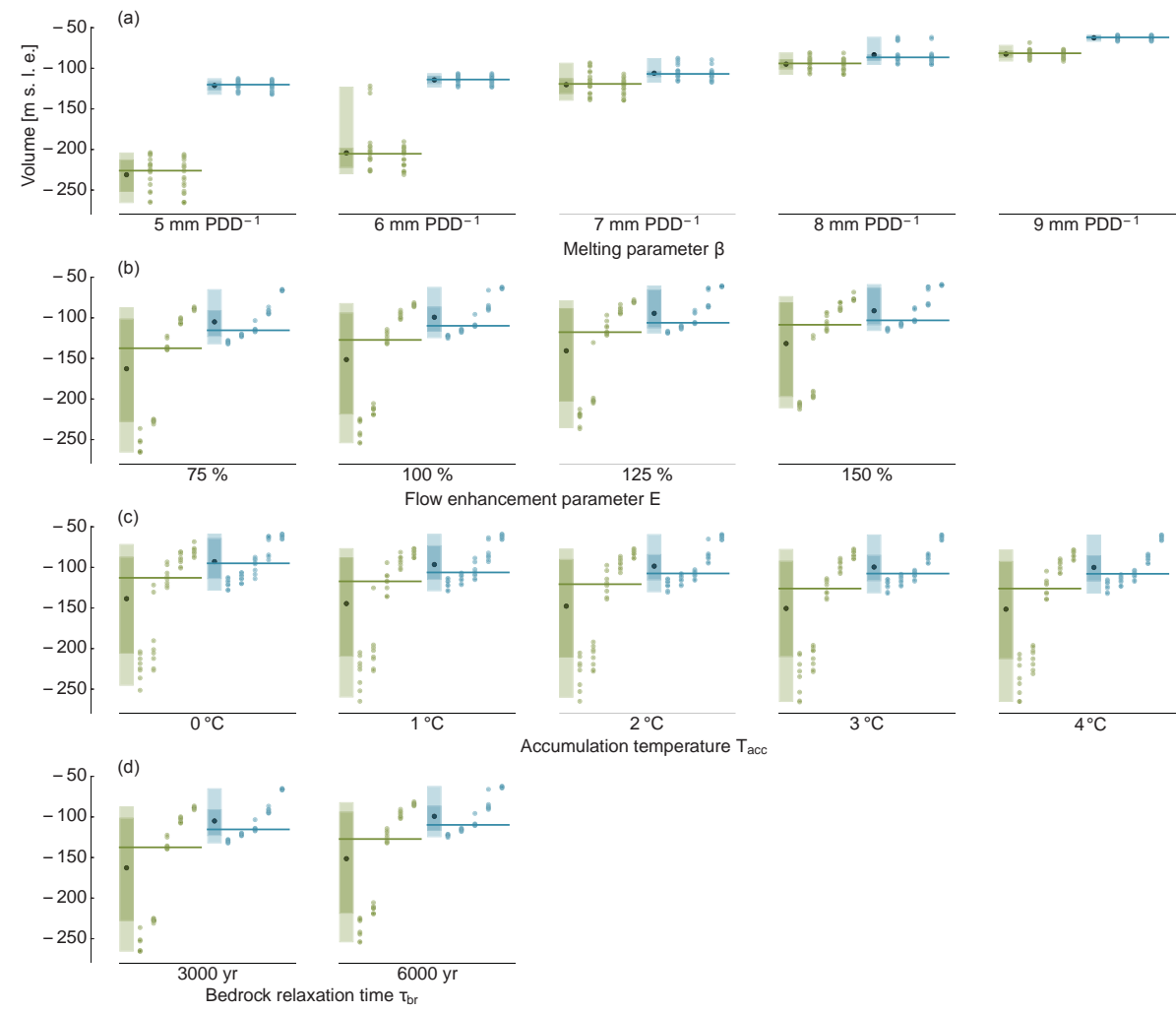

Figure 6. The dependence of the minimum sea level with respect to the different model parameters (rows) and climate forcing ( green $=\mathrm{LGM}_{\mathrm{uc}}$, blue $=\mathrm{LGM}_{\mathrm{bs}}$ ). The light colored boxes contain $95 \%$ of the simulations; the darker box contains half of the total. The median is drawn as a line, and the average as a black dot. The two columns of dots in one ensemble of panel (a) show the different values of $\tau_{\mathrm{br}}$. The columns of dots in panels (b-d) represent the five values of $\beta$ from the first panel.

Table 4. Distribution of ensemble members that simulate a LGM sea level anomaly consistent with reconstructions (see horizontal gray bar in Fig. 7, total 114 members). Mean values for all members listed below: $\beta=5.97 \mathrm{~mm} \mathrm{PDD}^{-1}, E=111 \%, T_{\mathrm{acc}}=2.09^{\circ} \mathrm{C}, \tau_{\mathrm{br}}=4526 \mathrm{yr}$.

\begin{tabular}{|c|c|c|c|c|c|c|c|c|c|c|c|}
\hline Variable & Value & No. members & & & & & & & & & \\
\hline \multirow[t]{5}{*}{$\beta$} & $5 \mathrm{~mm} \mathrm{PDD}^{-1}$ & 39 & \multirow[t]{5}{*}{$E$} & $75 \%$ & 30 & \multirow[t]{5}{*}{$T_{\mathrm{acc}}$} & $0{ }^{\circ} \mathrm{C}$ & 20 & \multirow{5}{*}{$\tau_{\mathrm{br}}$} & \multirow{5}{*}{$\begin{array}{l}3000 \mathrm{yr} \\
6000 \mathrm{yr}\end{array}$} & 56 \\
\hline & $6 \mathrm{~mm} \mathrm{PDD}^{-1}$ & 40 & & $100 \%$ & 30 & & $1^{\circ} \mathrm{C}$ & 22 & & & 58 \\
\hline & $7 \mathrm{~mm} \mathrm{PDD}^{-1}$ & 34 & & $125 \%$ & 27 & & $2^{\circ} \mathrm{C}$ & 24 & & & \\
\hline & $8 \mathrm{~mm} \mathrm{PDD}^{-1}$ & 1 & & $150 \%$ & 27 & & $3{ }^{\circ} \mathrm{C}$ & 24 & & & \\
\hline & $9 \mathrm{~mm} \mathrm{PDD}^{-1}$ & 0 & & & & & $4{ }^{\circ} \mathrm{C}$ & 24 & & & \\
\hline
\end{tabular}

Each tuning parameter (Table 3) has different influences on the maximum volume. Figure 6 illustrates the tendency and distribution of these tuning parameters. The melting parameter $\beta$ has the strongest influence on ice volume in comparison with other parameters. The mean sea level, as well as the 95th percentile, decreases with increases in $\beta$. This variation between different values of $\beta$ is also seen in the other diagrams, where different values of $\beta$ are shown as columns of dots. Generally, the width of the distribution also decreases with increasing $\beta$. A large jump in ms.l.e. is observed between 6 and $7 \mathrm{mmPDD}^{-1}$, which is also visible in the density distribution (Fig. 7, lower part). Simulations with an ice volume above $200 \mathrm{~m}$ s.l.e. tend to have a $\beta$ lower or equal than $7 \mathrm{~mm} \mathrm{PDD}^{-1}$, with three exceptions.

Compared to the impact of $\beta$ and the climate boundary conditions, the influence of all other model parameters on ice volume is relatively small. A weak influence of the flow enhancement parameter $E$ on maximum ice volume is apparent as faster ice flux leads to lower ice volumes. The lower bound increases faster with larger $E$, while the upper limit is almost fixed. Therefore, the group of isolated ensemble members with a low $\beta$ at the upper limit gets closer to the mean values of $E$. The mean and median are closer at a higher ice flux. The influence of the accumulation temperature $T_{\text {acc }}$ maximum ice volume is very small. Higher $T_{\text {acc }}$ results in slightly 


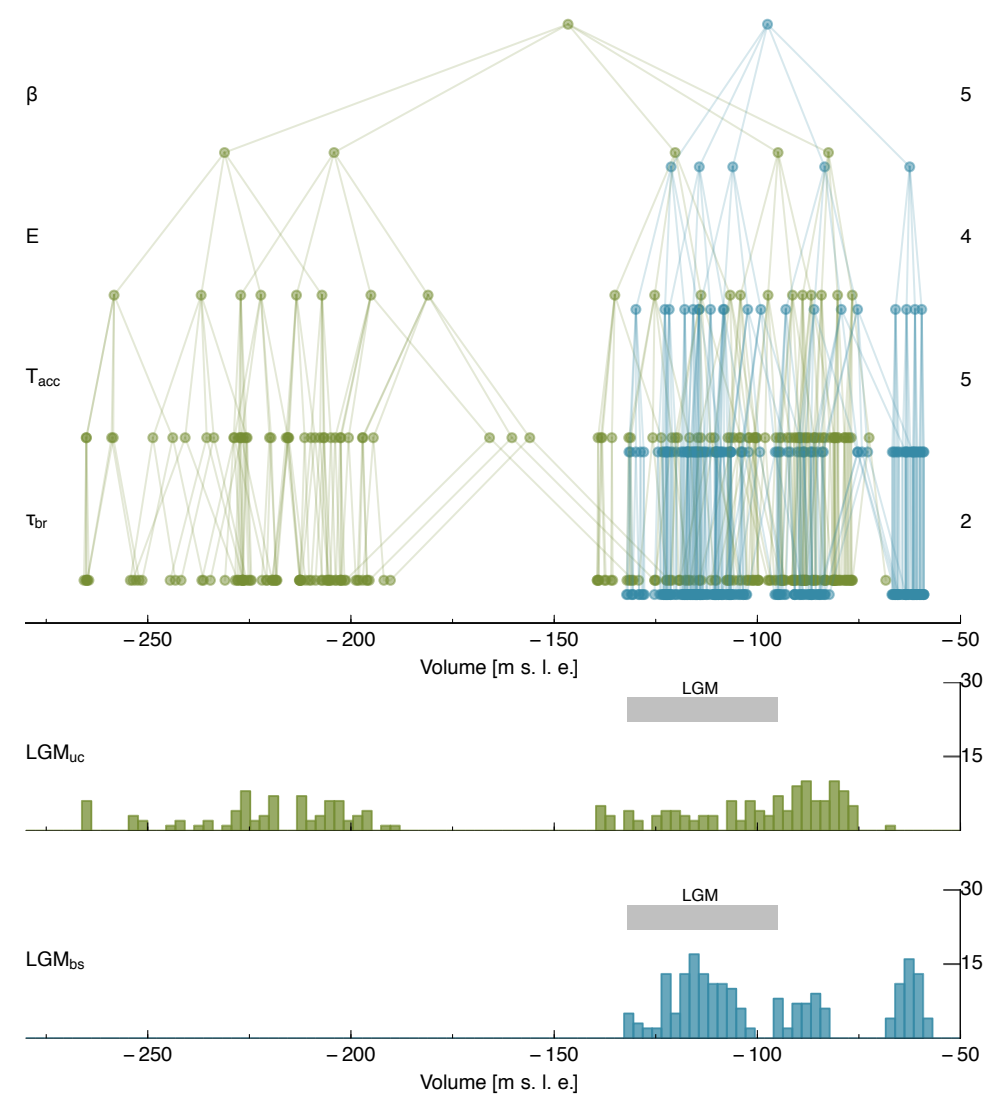

Figure 7. Structured parameter tree for the distribution of the minimum sea level with respect to the influence of each tuning parameter. Each layer is represented by a tuning parameter; the number of different tuning parameter values is shown on the right $y$ axis. The gray horizontal bar corresponds to the sea level decrease in the LGM in the Northern Hemisphere from Clark and Mix (2002).

Table 5. Subset of tuning parameters with 18 members and their used values for a hysteresis ensemble (Fig. 11a).

\begin{tabular}{llll}
\hline Name & Abbreviation & Unit & Values \\
\hline Melting parameter & $\beta$ & $\mathrm{mm} \mathrm{PDD}^{-1}$ & $5 ; 6 ; 7$ \\
Accumulation temperature & $T_{\mathrm{acc}}$ & ${ }^{\circ} \mathrm{C}$ & $2 ; 3 ; 4$ \\
Flow enhancement parameter & $E$ & $\%$ & $75 ; 100$ \\
Bedrock relaxation time & $\tau_{\mathrm{br}}$ & $\mathrm{yr}$ & 3000 \\
\hline
\end{tabular}

higher ice volumes because it leads to more accumulation. No apparent difference is visible between the two bedrock relaxation timescales $\tau_{\mathrm{br}}$. This result is not unexpected because $\tau_{\text {br }}$ only impacts the transient bedrock sinking during the ice sheet build-up, not the maximum ice volume shown here. The median and mean, as well as the percentile boxes, are similar for both bedrock relaxation times.

Figure 7 is separated into two parts. Both share the horizontal axis that represents the total ice volume in $\mathrm{ms}$.l.e. The upper part is a tree plot, where each layer represents one specific tuning parameter to illustrate the spread they cause. At the bottom all individual simulations are shown. From bottom to top, simulations are averaged parameter-wise at each level. Thus, the ice volume range caused by variations in each individual tuning parameter is shown by the divergent lines from the top down. The highest point is the average of all ensemble simulations. The two ensembles are shown in different colors to before. As an example, each of the 20 points of one climate forcing at the third layer from the top represents the average of all combinations of $T_{\mathrm{acc}}$ and $\tau_{\mathrm{br}}$. As this level illustrates the impact of $E$, four points representing the different considered values of this variable connect into one single dot at their average position of the level above. This yields five different dots, each representing one of the possible values of $\beta$. For better readability, the parameters have been ordered so that the one with the greatest influence on minimum ice volume is on top $(\beta)$ and the least sensitive at the bottom $\left(\tau_{\mathrm{br}}\right)$. With the information about the tendency of 
the ice volume change with respect to the parameter variations (Fig. 6) it is possible to address the individual values (Table 3) at each parameter branch. The lower part of this figure shows a density distribution of the ice volume for each climate forcing. It is consistent with the points of the last row in the upper part and distributes these among 100 classes over the whole bandwidth.

The tree plot shows that the influence of the tuning parameter on the ice volume has a clear order. Nevertheless, there are a few examples where the points change the position and join a cluster of another branch. The most prominent examples are six simulations with different bedrock relaxations which have a gap of more than $80 \mathrm{~m}$ s.l.e. and each of them is positioned exactly on one side of the big split. A longer relaxation time leads to larger ice volumes, because ice sheets can grow faster with a long relaxation time and may stabilize at this larger volume because the surface elevation remains longer at high altitudes with positive surface mass balance.

The density distribution shows a non-normal distribution for every ensemble of different climate forcing. $\mathrm{LGM}_{\mathrm{uc}}$ has two obvious groups with a gap of roughly $50 \mathrm{~m}$ s.l.e. The group with the lower sea level consists of $\beta$ configurations with 5 and $6 \mathrm{mmPDD}^{-1}$ (see Fig. 6), and the group with the upper sea level includes all $\beta$ greater than and equal to $7 \mathrm{~mm} \mathrm{PDD}^{-1}$. Responsible for this gap is the North American ice sheet. During the build-up process of the North American ice sheet the Laurentide (eastern part) and Cordilleran (western part) ice streams join together into a single ice body. Simulations in the $\mathrm{LGM}_{\mathrm{uc}}$ ensemble with an ice volume greater than $225 \mathrm{~m}$ s.l.e. consist of a single North American ice sheet, while in simulations with a lower ice volume these two streams are not in contact with each other. The $\mathrm{LGM}_{\mathrm{bs}}$ is also separated into two groups, but the width of the gap is only around $10 \mathrm{~m}$ s.l.e. Again, the two groups are mostly defined by different values of $\beta$ and the connection of the Laurentide and Cordilleran ice stream to the North American ice sheet.

Figure 7 highlights potential LGM ice volumes (Clark and Mix, 2002) as gray horizontal bars in the density distribution. The lower limit at $-95 \mathrm{~m}$ s.l.e. is based on Peltier (2002), while the upper limit at $-132 \mathrm{~m}$ s.l.e. corresponds to the maximum CLIMAP reconstruction (Denton, 1981) for the Northern Hemisphere in both cases. The ICE-5G reconstruction from Peltier (2004) with $-117 \mathrm{~m}$ s.l.e. is located in the center of the bar. This last reconstruction was used as a topography boundary condition in the CCSM4 climate simulations that were used to force the ice sheet model. Additional reconstructions by Waelbroeck et al. (2002) and Peltier et al. (2015) also fall within this range. Simulations within the range of this bar are considered as suitable LGM simulations for the further analysis. While the older reconstructions are arguably less robust, we note that they are consistent with the range of uncertainty of even the most recent ones. Thus, we consider the range provided here suitable to constrain the ensemble. Note that while the real-world ice sheets prob- ably did not reach an equilibrium during the LGM (Clark et al., 2009; Heinemann et al., 2014), the simulations here are forced with an LGM climate until their volume equilibrates. We assume that this uncertainty does not exceed the range of reconstructions. The $\mathrm{LGM}_{\mathrm{uc}}$ ensemble has 50 possible LGM simulations, while 114 simulations are considered from $L_{G M}$ climate forcing. The averages of these simulations for each respective climate forcing look quite different (Fig. 8), although these two ensemble composites differ in their ice volume by only $3 \mathrm{~m}$ s.l.e.

The most obvious difference between the two composites is the North American ice sheet. The ice flows from two different streams, the Laurentide and Cordilleran ice sheets, towards the Great Plains. With the $\mathrm{LGM}_{\mathrm{uc}}$ forcing, these two streams are not connected in any simulation. A gap in the Great Plains remains. This is due to higher temperatures in the Great Plains in the $\mathrm{LGM}_{\mathrm{uc}}$ ensemble than in the corrected version (Fig. 3). Therefore, with $\mathrm{LGM}_{\mathrm{bs}}$ forcing, the Laurentide and Cordilleran ice streams connect easier and faster compared to the uncorrected ensemble but the two domes remain separated. This is consistent with the ICE-5G reconstruction that also suggests two distinct domes on the North American ice sheet (Fig. 9, right). While the separation in our simulations is stronger because the Hudson Bay remains below sea level and therefore ice-free, a more pronounced separation is consistent with the recent ICE-6G reconstruction (Peltier et al., 2015).

In the $\mathrm{LGM}_{\mathrm{bs}}$ simulations, the Eurasian ice sheet accumulates less ice compared to the uncorrected version. The British Isles and Scandinavia are covered by ice in both ensembles. The Eurasian ice sheet in the $\mathrm{LGM}_{\mathrm{uc}}$ ensemble without the temperature bias correction consists of one large ice sheet with a connected and distinct eastern part. Whereas the ensemble $\mathrm{LGM}_{\mathrm{bs}}$ has two individual small Eurasian ice sheets of almost equal expansion. The model accumulates ice in the Alps in both ensembles which are discrete from other ice masses. The $\mathrm{LGM}_{\mathrm{uc}}$ accumulates more ice in Eurasia and is therefore closer to ICE-5G. Nevertheless, both climate forcings underestimate the ice volume in Eurasia. The constant and dry LGM climate forcing may be responsible for the reduced Eurasian ice sheet.

The Bering Strait and the Asian far east region in $\mathrm{LGM}_{\mathrm{bs}}$ ensemble are similar to the ICE-5G reconstruction (Fig. 9, right). The $\mathrm{LGM}_{\mathrm{uc}}$ ensemble accumulates ice in the North American part of the Bering Strait, whereas the ice in the $\mathrm{LGM}_{\mathrm{bs}}$ ensemble and ICE-5G reconstruction is in this part not that distinct. Ziemen et al. (2014) attribute the overestimated accumulation in this region to the missing albedo variation in their model and moisture blocking of the atmospheric forcing. The land around the New Siberian Islands is covered by a small ice sheet in both ensembles, while this area is ice-free in the LGM ICE-5G reconstruction.

Overall, the results with $\mathrm{LGM}_{\mathrm{bs}}$ forcing are closer to the LGM reconstruction. Besides the relatively small Eurasian ice sheet, the ice distribution is closer to ICE-5G in all con- 

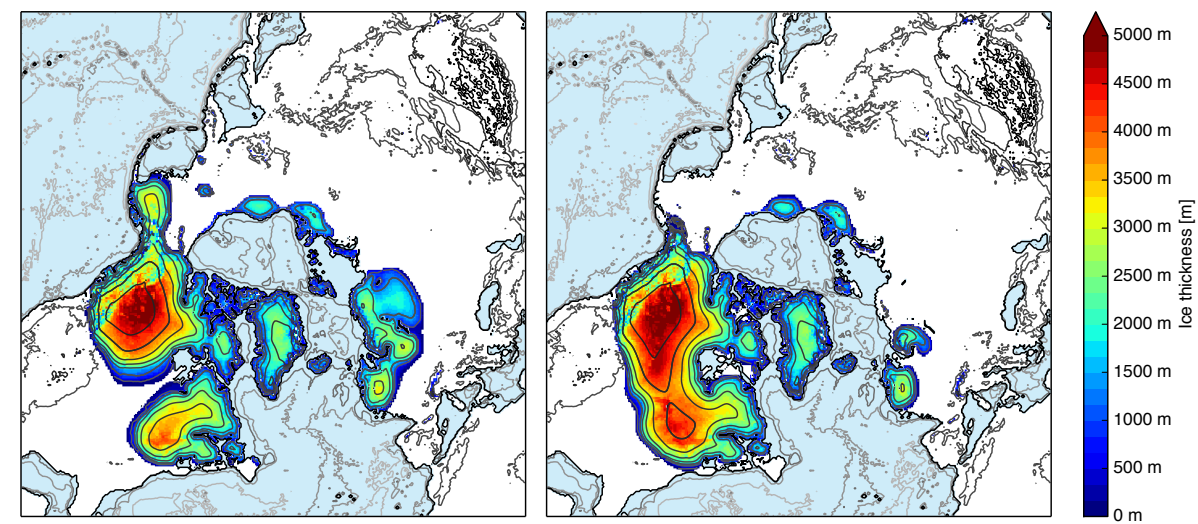

Figure 8. Ensemble composite of all simulations within LGM ice volume range of -132 and $-95 \mathrm{~m}$ s.l.e. (see gray horizontal bar in Fig. 7) (Clark and Mix, 2002). Ensemble LGM $_{\mathrm{uc}}$ (left, mean -111.9 m s.l.e.) consists of 50 simulations, and LGM $\mathrm{bs}_{\mathrm{bs}}$ climate forcing (right, mean -114.7 m s.l.e.) has 114 members.
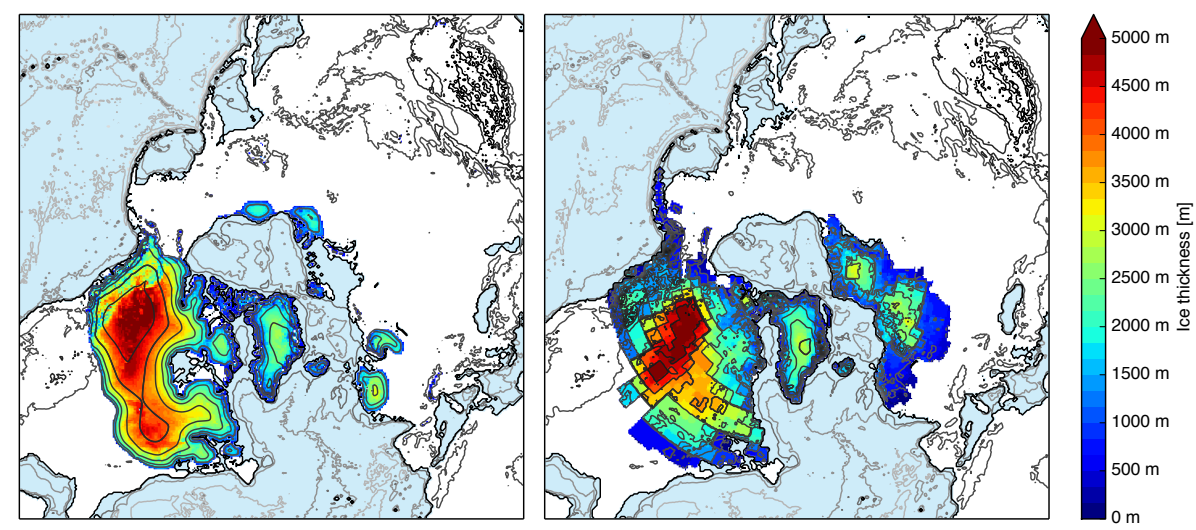

Figure 9. Simulation with the best-guess tuning parameters proximate to the mean values from Table 4 of all considered $\mathrm{LGM}_{\mathrm{bs}}$ simulations within the LGM ice volume range (gray horizontal bar in Fig. 7) on the left. Parameters: $\beta=6 \mathrm{mmPDD}^{-1}, E=100 \%, T_{\mathrm{acc}}=2^{\circ} \mathrm{C}$, $\tau_{\mathrm{br}}=3000 \mathrm{yr}$. Ice volume: $-115 \mathrm{~ms}$.1.e. ICE-5G from Peltier (2004) with an ice volume of $117 \mathrm{~ms} .1 . \mathrm{e}$. in the Northern Hemisphere on the right.

sidered $\mathrm{LGM}_{\mathrm{bs}}$ ensemble members than the ones from the $\mathrm{LGM}_{\mathrm{uc}}$ ensemble. The spread of the maximum ice volume (Fig. 6) is narrow, and more than half of all $\mathrm{LGM}_{\mathrm{bs}}$ simulations are considered valid in terms of minimum LGM sea level compared to only one-quarter of all $\mathrm{LGM}_{\mathrm{uc}}$ simulations. Therefore, the following discussion focuses on the ensemble $\mathrm{LGM}_{\mathrm{uc}}$ simulations.

Table 4 shows the distribution of all tuning parameters from all $114 \mathrm{LGM}_{\mathrm{bs}}$ simulations with an ice volume between 95 and $132 \mathrm{~ms}$ s.l.e. (see Fig. 7). The average ice thickness of these simulations is shown as an ensemble composite in Fig. 8 (right). The average value for $\beta$ for all 114 simulations is $5.97 \mathrm{mmPDD}^{-1}$, while their values are approximately evenly distributed between 5 and $7 \mathrm{~mm} \mathrm{PDD}^{-1}$. For the flow enhancement factor $E$, most simulations consistent with reconstructions have values of 75 and $100 \%$ with an average of $111 \%$. The accumulation temperature $A_{\text {temp }}$ shows a slight tendency towards warmer temperatures and the two bedrock relaxations $\tau_{\text {br }}$ are distributed almost equally.

Representing the average over a large number of potentially very different simulations of ice distribution with different model parameters, the composites are not physically consistent. Thus, the composite for $\mathrm{LGM}_{\mathrm{bs}}$ is now compared with the equilibrium state of the simulation whose parameters are closest to the mean value of the parameters of the ensemble composite $\left(\beta=6 \mathrm{~mm} \mathrm{PDD}^{-1}, E=100 \%\right.$, $T_{\text {acc }}=2{ }^{\circ} \mathrm{C}, \tau_{\mathrm{br}}=3000 \mathrm{yr}$; Table 4). The situation in Eurasia, Greenland and the Bering Strait is very similar between this simulation (Fig. 9, left) and the ensemble composite (Fig. 8, right). Nevertheless, there are small differences at the North American ice sheet between these two results. The single simulation consistent with the approximate mean values shows indications of a single-dome North American ice sheet, whereas the two individual domes that merge to form the North American ice sheet, consistent with reconstruc- 

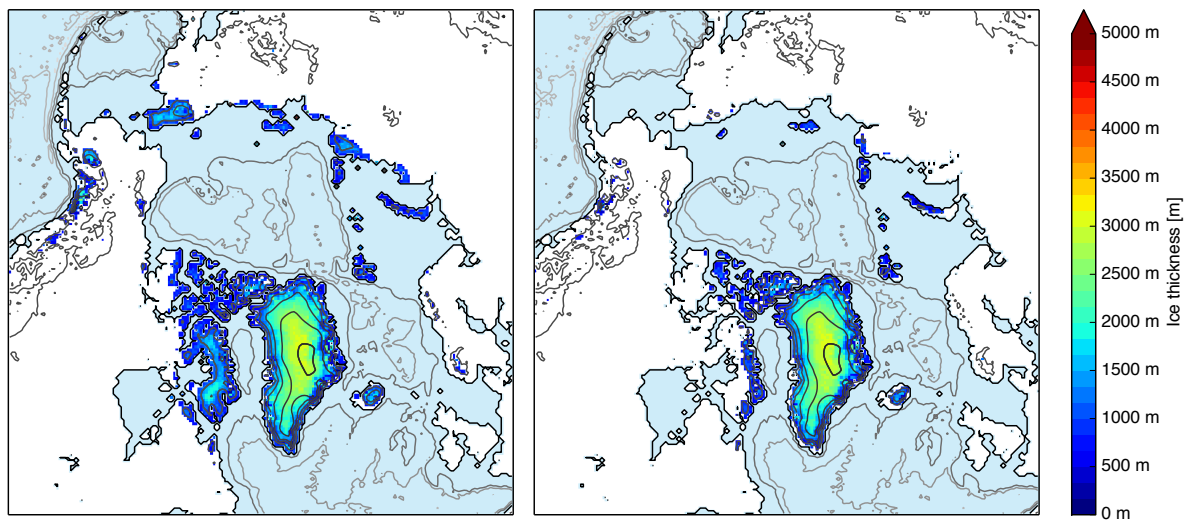

Figure 10. Ice distribution in the Northern Hemisphere for uncorrected preindustrial conditions (PI $\mathrm{uc}_{\mathrm{uc}}$, left) and with subtracted temperature bias $\left(\mathrm{PI}_{\mathrm{bs}}\right.$, right). Simulated ice volumes correspond to $-8.2 \mathrm{~ms}$.1.e. $-4.1 \mathrm{~ms}$.l.e., respectively, where the difference is mainly due to ice masses outside Greenland.

tions (Stokes et al., 2012; Kleman et al., 2013), are still visible in the ensemble composite. Both the single simulation and the ensemble composite have a very similar total ice volume of approximately $115 \mathrm{~m}$ s.l.e. However, the former is in overall better agreement with ICE-5G from Peltier (2004). Therefore, these parameters are considered to be the bestguess tuning parameters (Table 1). For further investigations, only this parameter set is considered.

Simulations at the upper limit of the LGM sea level at $130 \mathrm{~ms}$.l.e. have a similar ice distribution in Eurasia as the simulation with the best-guess tuning parameters (not shown). The additional ice volume is mainly due to thicker ice in the same regions as in Fig. 9 (left) and does not add to the ice sheet area. All simulations with realistic LGM sea level underestimate the Eurasian ice sheet.

\subsection{Preindustrial climate forcing}

The IceBern2D is strongly dependent on the surface mass balance and the tuning parameters $\beta$ and $T_{\text {acc }}$ directly related to it. To benchmark the best-guess tuning parameters (values in Table 1) from the $\mathrm{LGM}_{\mathrm{bs}}$ simulation, IceBern2D is applied in the Northern Hemisphere under preindustrial conditions (Table 2). Furthermore, this allows for cross-validation of the model performance with the best-guess tuning parameters and a different climate forcing.

Both versions of preindustrial forcing without the temperature bias $\left(\mathrm{PI}_{\mathrm{uc}}\right.$ and $\left.\mathrm{PI}_{\mathrm{bs}}\right)$ do not accumulate significant ice volumes in the Northern Hemisphere (Fig. 10) with the best-guess tuning parameters $\left(\beta=6 \mathrm{~mm} \mathrm{PDD}^{-1}, T_{\text {acc }}=\right.$ $2^{\circ} \mathrm{C}, E=100 \%$ and $\tau_{\mathrm{br}}=3000$ years). The ice volumes correspond to $-8.2 \mathrm{~m}$ s.l.e., and $-4.1 \mathrm{~m}$ s.l.e., respectively, with the most suitable tuning parameters where the positive offset of $7.36 \mathrm{~m}$ s.l.e. from Greenland is already subtracted from the values. The most conspicuous difference between the two climate forcings is on Baffin Islands and Chukotka in far eastern Siberia. The forcing without the temperature bias $\left(\mathrm{PI}_{\mathrm{bs}}\right)$ ac- cumulates much less ice in this area, and the result is more realistic. Both climate forcings result in very similar ice volume of Greenland with $10.0 \mathrm{~ms}$.l.e. $\left(\mathrm{PI}_{\mathrm{uc}}\right)$ and $9.9 \mathrm{~ms}$ s.l.e. $\left(\mathrm{PI}_{\mathrm{bs}}\right)$. This exceeds the ice volume of Bamber et al. (2013) by $2.6 \mathrm{~m}$ s.l.e. This difference is primarily due to the relatively coarse resolution of the model, which does not resolve the narrow ablation zone of the Greenland ice sheet with sufficient detail. Moreover, a large part of the ice loss on Greenland is due to calving through narrow outlet glaciers (van den Broeke et al., 2009; Straneo and Heimbach, 2013). This efficient mechanism of ice discharge is also not represented here because it requires both a high resolution of the narrow coastal fjord landscape and higher-order ice dynamics that are inconsistent with the shallow-ice approximation that our model is based on. As a consequence, the margin of the simulated Greenland ice sheet is too close to the coast, which accounts for the additional ice volume as compared to observations. These shortcomings are probably less important for the simulation of the large continental ice sheets of the LGM, because they are largely based on flat terrain and have less steep slopes and therefore a broader ablation zone and a smaller fraction of their margins is near the ocean.

\subsection{Multiple equilibria in Northern Hemisphere ice volume}

One of the primary advantages of the ice sheet model is its computational efficiency and hence the possibility for large ensemble simulations and long integration times. Here, a reduced ensemble of 18 parameter combinations (Table 5) has been forced with the $\mathrm{LGM}_{\mathrm{bs}}$ data and a slowly varying global temperature offset. Temperature anomalies have been linearly decreased from +5 to $-5^{\circ} \mathrm{C}$ over 2.5 million years and increased again to $+5^{\circ} \mathrm{C}$ in the same way. The maximum temperature offset corresponds to the temperature difference between the CCSM4 LGM and PI simulation of $4.97 \mathrm{~K}$ in the Northern Hemisphere (Table 2). One simulation had numeri- 

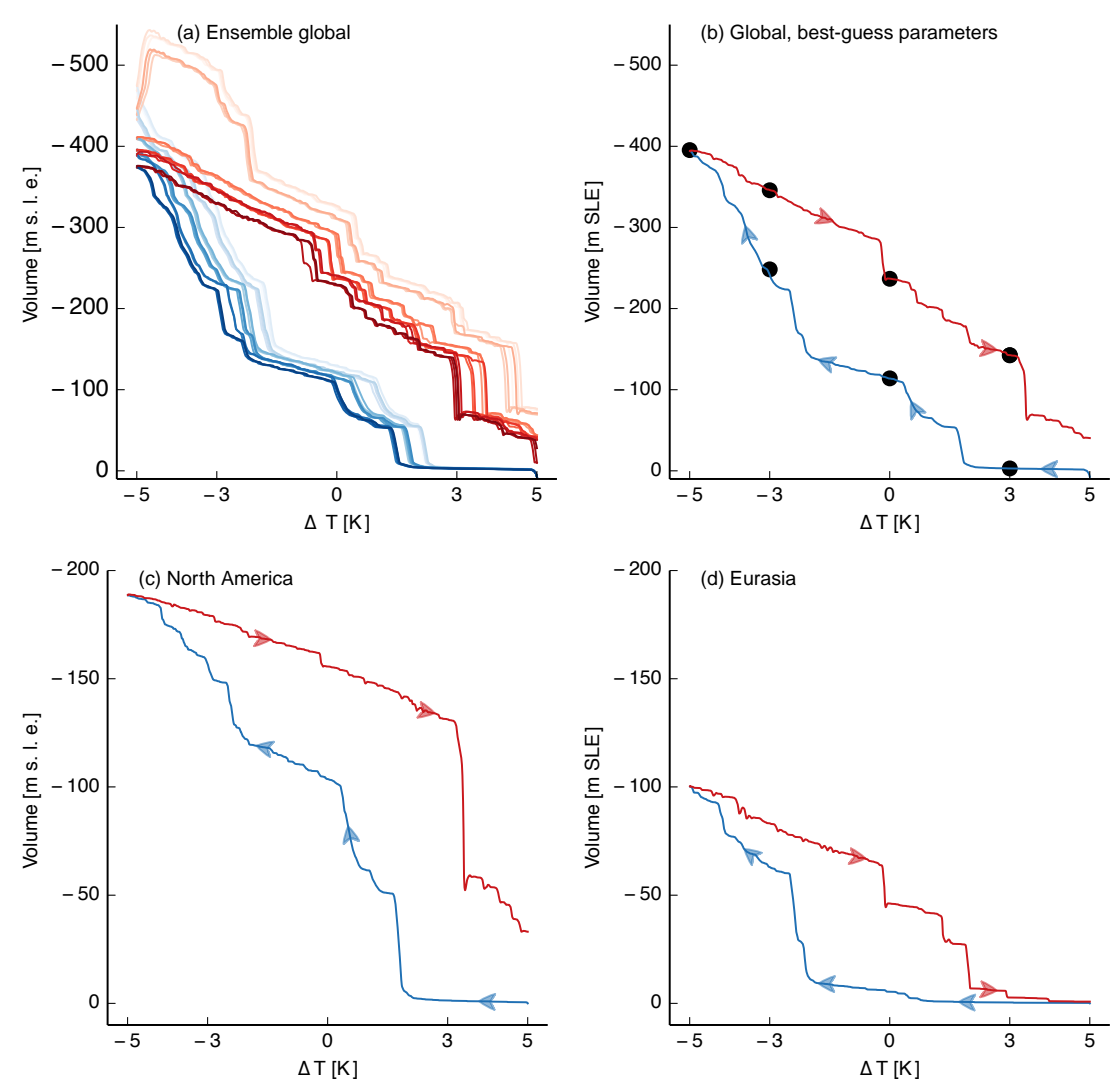

Figure 11. Global (a, b) and regional (c, $\mathbf{d})$ ice volume as a function of global temperature offset. Increasing temperatures are in blue, and decreasing temperatures in red. On the top left (a) is an ensemble with 18 members (Table 5) indicating the robustness of the hysteresis behavior in a range of parameter values. All other plots (b-d) are from the simulation with the best-guess parameter (same as in Fig. 9, left). The dots denote (b) the ice volume in equilibrium at the specific temperature. Considered areas for North American and Eurasia are highlighted in Fig. 12.

cal instabilities after 4.5 million years and was not considered in the results.

To ensure that the rate of temperature change is slow enough for the ice sheet to remain in continuous quasiequilibrium, seven simulations were carried out with the best-guess parameter set in which the temperature change was interrupted at different values. These simulations continued with a constant temperature offset for 100000 years (Fig. 11, black dots on the right). These interrupted runs confirm that the transient simulation is a good approximation to a continuous equilibrium.

The ice volume as a function of the temperature offset describes a hysteresis (Fig. 11). There are two stable equilibria for almost every temperature, depending on the initial value of the ice volume. This is valid globally as well as for the individual regions North America and Eurasia (Fig. 11c and d). In contrast to the global ice volumes $(a, b)$, the regional ice volumes in Fig. 11c and d have no global sea level offset of $7.36 \mathrm{~m}$.

Different tuning parameters have a modest influence on the overall shape of the hysteresis and major transitions
(Fig. 11a). A slight horizontal shift to a later or earlier ice volume change is visible. Simulations with the same melting parameter $\beta$ are close together and identify as three individual groups at the build-up of the ice sheet. All six simulations with a $\beta$ of $5 \mathrm{~mm} \mathrm{PDD}^{-1}$ reach ice volumes greater than $500 \mathrm{~m}$ s.l.e. and are not in equilibrium at the cold extreme of the forcing range. The reason for this additional ice growth is a large region in central Siberia where surface mass balance becomes positive. This illustrates that the open southern boundaries on both major land masses complicate the definition of the hysteresis loop, because the upper limit is not limited by continental boundaries. Nevertheless, the evolution of all ensemble members is similar, which justifies limiting the detailed discussion to the single hysteresis simulations with the best-guess parameter set (Fig. 11b-d)

There are three processes which influence rapid ice volume changes. They can be seen in the hysteresis (Fig. 11) as an almost vertical volume change. Firstly, the most important influence is the positive ice elevation feedback. As soon as the surface temperature reaches a certain level where the surface mass balance turns positive, the ice sheet grows fast 
to higher and colder elevations and stabilizes itself. Adjacent areas may be influenced by the ice flow from these newly glaciated regions, so that the surface mass balance turns positive there too. A positive feedback is induced which is much faster compared to the temperature change in the hysteresis (Fig. $11 \mathrm{c}$, at $2^{\circ} \mathrm{C}$ ).

Secondly, another strong influence during the build-up process on the ice volume is the contact of two individual ice sheets over eastern (Laurentide) and western (Cordilleran) North America that combine to form the North American ice sheet. Although we use an idealized forcing, this evolution is consistent with reconstructions of the last glaciation (Bintanja and van de Wal, 2008; Stokes et al., 2012; Kleman et al., 2013). The ice volume increases considerably as soon as these two streams connect with each other (Fig. 11c, at $0.5^{\circ} \mathrm{C}$ ) because ice flows from two different directions into the center of the continent. The connection of these two streams is responsible for the jump of roughly $40 \mathrm{~m}$ s.l.e. The ice volume in North America decreases steadily and relatively slowly on the descending branch of the hysteresis until a positive temperature offset of $3{ }^{\circ} \mathrm{C}$. At higher temperatures the surface mass balance turns negative in the southern part. The Laurentide ice sheet is not in equilibrium with the underlying bedrock after this rapid ice loss. Therefore a small rebound of the ice volume is visible after the ice volume decrease of almost $100 \mathrm{~m}$ s.l.e. (Fig. 11c).

Thirdly, the sea level change due to formation of ice on land has an important indirect influence on the ice distribution, especially in Europe. Ice sheets isolated by water masses, i.e., the British Isles or Scandinavia, are not able to bypass these barriers because IceBern2D does not include floating ice shelves. However, if the water level drops below a certain level, areas previously separated by water join and ice can expand into new regions. The sea level change may have an immediate effect if the ice sheet is already in contact with the water barrier and can expand in regions that become dry land, e.g., the Grand Banks of Newfoundland, in agreement with previous studies (de Boer et al., 2013).

At the beginning of the hysteresis, at temperatures above $2.5^{\circ} \mathrm{C}$, the Northern Hemisphere apart from Greenland is nearly ice-free. After one complete hysteresis loop, most of the simulations reach a similar ice volume at the initial temperature offset of $\Delta+5^{\circ} \mathrm{C}$ than at the ice-free beginning. However, the simulation with the best-guess parameter set does not become ice-free at the end of the hysteresis. The North American ice sheet in particular still has some remarkable volume, while the Eurasian ice sheet disappears around $4{ }^{\circ} \mathrm{C}$ (Fig. 11c and d).

The difference in ice volume between the ascending and descending branches of the hysteresis at a temperature offset of $\Delta T=0^{\circ} \mathrm{C}$, i.e., with the $\mathrm{LGM}_{\mathrm{bs}}$ forcing, is $123 \mathrm{~m}$ s.l.e. The shape and distribution of the simulated ice sheets on the lower branch of the hysteresis after 1.25 million years is virtually indistinguishable from the equilibrium of the simulations with constant forcing shown in Sect. 4.1 (Fig. 9,

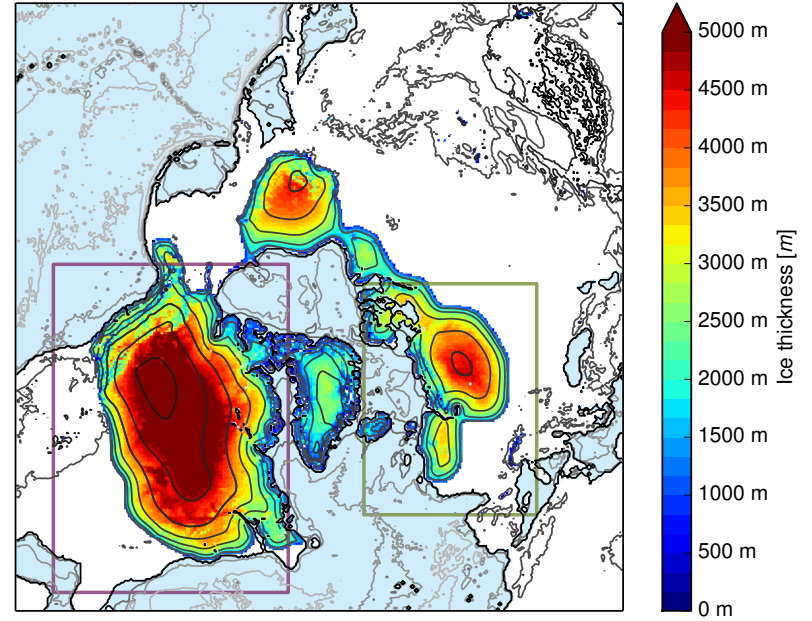

Figure 12. Hysteresis after 3.75 million years at LGM temperature $\left(\Delta 0^{\circ} \mathrm{C}\right)$ with an ice volume of $236.7 \mathrm{~ms}$.l.e. The situation at the same temperature at the build-up process of the ice sheet after 1.25 million years can be seen in Fig. 9 (left). Areas of North America and Eurasia from Fig. 11c and d are enclosed in purple and green boxes, respectively.

left). Figure 12 shows the ice thickness for $\Delta T=0^{\circ} \mathrm{C}$ after 3.75 million years on the upper branch of the hysteresis. All ice masses but Greenland are considerably larger, amounting to about $50 \mathrm{~m}$ s.l.e. in North America alone. The extent of the North American ice sheet is mostly the same as on the lower branch of the hysteresis as it does not extend further south. The only major difference in ice is the fully ice-covered Hudson Bay due to the intermittently lower sea level. The ice volume difference in Eurasia is roughly $40 \mathrm{~m}$ s.l.e., but during the build-up process Eurasia is nearly ice-free. Therefore, the relative difference volume of the hysteresis in Eurasian ice is very large (Fig. 11d). At the LGM temperature $\Delta T=0^{\circ} \mathrm{C}$ on the lower branch, only two small ice sheets are present in Scandinavia and the British Isles. On the upper branch, the Eurasian ice sheet stretches all the way from the British Isles to far eastern Siberia.

A constant climate forcing is not representative of the entire last glacial cycle, which partly explains the underrepresented Eurasian ice sheet in the uninitialized LGM simulations and on the lower branch of the hysteresis. During the last glaciation, the climate over Europe continuously varied, also in response to the growing North American ice sheet, which had pronounced consequences for the temperature and the path of moisture-bearing storms over Europe ( $\mathrm{Li}$ and Battisti, 2008; Liakka et al., 2015). The LGM climate of CCSM4 is considerably dryer over Scandinavia and western Siberia (Fig. 2), two key regions for the glacial inception over Eurasia (Svendsen et al., 2004). Thus, it is conceivable that the Eurasian ice sheet would not have grown in a continuous LGM climate but in fact accumulated most of its volume during preceding colder or wetter periods. Such variations 
in temperature or precipitation are not included in the constant LGM forcing employed here. However, the temperature forcing that defines the hysteresis simulation does promote ice growth over Eurasia and therefore partly recovers the effect of a variable glacial climate. This view is supported by the large and stable Eurasian ice sheet on the upper branch of the hysteresis that resembles the ICE-5G reconstruction more closely (Figs. 12 and 9, right). The additional $30 \mathrm{~m}$ s.l.e. of ice to explain the lower to upper hysteresis difference at $\Delta T=0{ }^{\circ} \mathrm{C}$ is found in Siberia but outside the region that was covered by the Eurasian ice sheet in reconstructions (see Fig. 12) (Svendsen et al., 2004). At the same temperature offset, this area is nearly ice-free on the lower branch of the hysteresis.

Besides the hysteresis of equilibrium ice volume, interesting additional information is obtained from simulations with rapid temperature transitions (Fig. 13). For each long-term equilibrium simulation on both branches of the hysteresis at $\{-3,0,+3\}^{\circ} \mathrm{C}$, two simulations are started with a relatively fast temperature increase or decrease, respectively. This transient anomaly is imposed at a rate of $1^{\circ} \mathrm{C} 1000 \mathrm{yr}^{-1}$, so that a $3{ }^{\circ} \mathrm{C}$ change in temperature is applied over 3000 years, the bedrock relaxation timescale. This rate of change is comparable to the general pace of the last deglaciation (Buizert et al., 2014). Nevertheless, as seen in the almost horizontal lines in Fig. 13, the change is quasi-instantaneous for the ice sheets. A second set of experiments with instantaneous temperature jumps yields identical results (not shown). After the transient change in temperature, all six simulations are run into equilibrium for 100000 years.

All decreases in the temperature anomaly that start on the lower branch of the hysteresis find their new equilibria on the hysteresis again, coinciding with the long-term equilibrium simulations that do not include a rapid temperature change. However, all but one of the simulations of rapid warming find new steady states that are below that of their corresponding equilibrium simulation on the hysteresis. This result does not depend on whether the warming starts from the upper or lower branch of the hysteresis. This is the effect of the slow adjustment of the bedrock. Starting with a relatively large ice volume, the bedrock is depressed below the steady state that corresponds to the new temperature offset after the rapid warming. This entails that the ice surface is also located at a lower elevation, which makes the rapid warming of the transition more effective. Interestingly, although this effect pushes the new steady state of the transient temperature perturbation to below the upper branch of the hysteresis, it is not enough to stabilize the transient simulation on the lower branch of the hysteresis either. In fact, new equilibria are found between the two original branches. This illustrates that the response to a transient warming from a larger ice volume is influenced by two counteracting mechanisms: the destabilizing bedrock effect due to the initially large ice mass and the stabilizing effect of that large mass of ice itself.

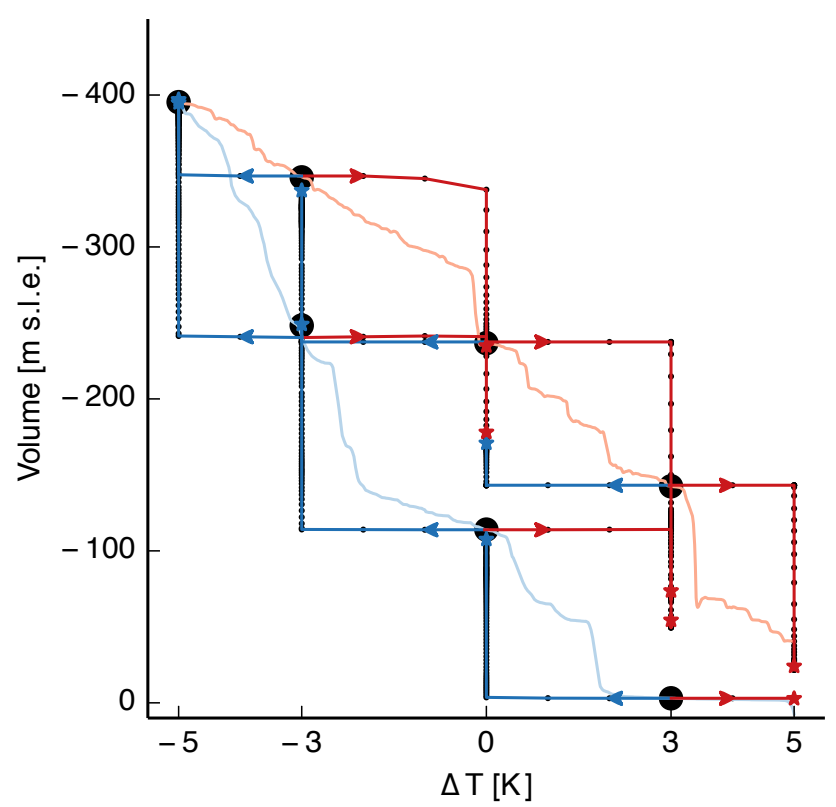

Figure 13. Global ice volume of simulations with a rapid temperature transitions of $1^{\circ} \mathrm{C}$ per 1000 years. The base of the transition simulations is the hysteresis simulation from Fig. 11 (b), which is shown in the background in pale colors. The large black dots are identical to the dots in Fig. 11 and mark the equilibrium state at the specific temperature. Simulations are started from $\{-3,0$, $+3\}^{\circ} \mathrm{C}$ with temperature increase (red) or decrease (blue) of $1{ }^{\circ} \mathrm{C}$ per 1000 years and a runtime of 100000 years (small black dots every 1000 years) until equilibrium (asterisks). The temperature difference of $3{ }^{\circ} \mathrm{C}$ is constantly applied in the first 3000 years and held stable thereafter.

The bedrock effect is of secondary importance for simulations that impose a rapid cooling, because here a lag in the sinking does not result in a loss of ice. In fact, it would accelerate the growth of ice, but since this process is generally much slower than melting, the bedrock has sufficient time to react to the increasing ice load and is generally closer to its equilibrium position than in the simulation with a rapid warming. Thus, an increase in global ice volume is the result. In two out of these three cases of cooling from the upper branch of the hysteresis, the new steady state is found on the upper branch of the hysteresis again. However, with the $3{ }^{\circ} \mathrm{C}$ cooling from an initial temperature offset of $+3{ }^{\circ} \mathrm{C}$, the endpoint is located between the two branches of the original hysteresis, close to that of the warming from $-3{ }^{\circ} \mathrm{C}$. As for the equilibrium hysteresis, these preferred points are defined by geographical characteristics.

In summary, the simulations with rapid temperature changes suggest that the one-dimensional hysteresis does not fully describe the complexity of the transient response of the ice volume. Additional equilibria are found that probably depend on the rate of warming and might be sensitive to the specific climate forcing that favors glaciation of certain regions. A generally higher stability of large ice volumes cannot be 
corroborated from these experiments because the ice loss of a relatively small ice volume can be substantial when the temperature offset after the rapid increase is near the threshold of destabilization of a regional ice mass, as observed in the warming from 0 to $+3{ }^{\circ} \mathrm{C}$. In this case, the rapid warming destabilizes a large part of the North American ice sheet even though this occurs only at slightly higher temperatures in the equilibrium hysteresis (Fig. 11c). It has been shown that such rapid ice loss events can happen even for relatively small ice sheets (Gregoire et al., 2012).

\section{Summary and discussion}

In this study, we present a model for continental-scale ice sheets that simplifies the dynamics of ice flow into a single, vertically integrated layer. The resulting two-dimensional flow is simulated on a rectangular domain that covers most of the land mass of the Northern Hemisphere. The surface mass balance uses the positive degree-day method (Reeh, 1991), based on daily fields of surface air temperature and total precipitation from the comprehensive global climate model CCSM4 (Gent et al., 2011; Merz et al., 2013). Global mean sea level is prognostically adjusted as a function of the simulated ice volume.

The simplified dynamics of the ice flow compare favorably in the standardized tests of the EISMINT project (Huybrechts et al., 1996). Similar models have been used to study the last glacial inception in Europe (Oerlemans, 1981a; Siegert et al., 1999) and the sensitivity of climate-ice sheet interactions during the last glacial cycle (Neeman et al., 1988). To obtain similar results that compare well with LGM reconstructions (e.g., Svendsen et al., 2004) with a present-day climate forcing, substantial adaptations are necessary (Siegert and Marsiat, 2001). Vertically integrated ice sheet models showed good results for applications on small regional scales (Näslund et al., 2003) and on a semi-hemispheric coarse grid (Neeman et al., 1988). Nevertheless, simulations on a fine grid over the Northern Hemisphere usually employ computationally more expensive three-dimensional models (Bonelli et al., 2009; Ganopolski and Calov, 2011; Robinson et al., 2011; de Boer et al., 2013) that often rival the climate models used to provide the external forcing in computational cost. This is not justified for all applications, because changes in climate and the resulting surface mass balance might dominate the influence of ice dynamics. We propose the combination of cost-efficient two-dimensional ice dynamics with a realistic domain of relatively high resolution, a tool that does not current exist. This enables the analysis of physically or stochastically seeded ensembles and probabilistic estimates of past and future ice sheet volumes.

Taking advantage of the computational efficiency of the model, a large set of simulations with perturbed parameters is used to optimize the simulation of Northern Hemisphere ice volume during the Last Glacial Maximum (Peltier, 2004).
Results show a reasonable agreement for North America, while the Eurasian ice sheet is too small. This is likely due to the lack of ice shelves in our model that does not allow the Barents Sea to be covered by ice and delays the development of an ice sheet on the Baltic and North Seas until the sea level is low enough for grounded ice to locally grow or advance into the area. This could be a problem as the marine ice sheets of the Barents and Kara seas have been shown to play a pivotal role early during the last glaciation (Svendsen et al., 2004). On regional scales the missing ice shelf may influence the results - i.e., the Hudson Bay would be covered by shelf ice, while it remains ice-free in IceBern2D LGM simulations. Furthermore, ice shelves buttress the ice sheet flow (Dupont and Alley, 2005). While the fundamentally different stress balance of ice shelves cannot be included in our model at this point, one possible solution is to allow the grounded ice to grow into deep water down to a certain water depth (Siegert et al., 1999; Tarasov and Peltier, 1999; Abe-Ouchi et al., 2013). Aside from these shortcomings, the optimized model version yields a realistic modern ice distribution when forced with simulated preindustrial climate from the same model.

The overestimated sea ice in the CCSM3 simulations (Collins et al., 2006) and the associated temperature bias influence the global ice sheet volume and its distribution. Simulations forced with the colder uncorrected climate $\left(\mathrm{LGM}_{\mathrm{uc}}\right)$ have a lower and a wider distribution of the ice volume. The temperature of the corrected ensemble $\left(\mathrm{LGM}_{\mathrm{bs}}\right)$ is on average $3{ }^{\circ} \mathrm{C}$ warmer. The simulated density distribution of ice volumes is therefore limited to a smaller bandwidth of a $3{ }^{\circ} \mathrm{C}$ warmer climate with an ice-free Northern Hemisphere as the lower limit. Local temperature corrections in the $\mathrm{LGM}_{\mathrm{bs}}$ ensemble overall lead to results which are comparable to LGM reconstructions such as ICE-5G.

Although the ice sheets during the LGM were not in equilibrium (Clark et al., 2009; Heinemann et al., 2014), all simulations are forced until an equilibrium is achieved. It takes around $120 \mathrm{kyr}$ with a constant climate forcing until a steady state of all ice sheets is reached. LGM cycles in the past $500 \mathrm{kyr}$ are around $100 \mathrm{kyr}$ (Hays et al., 1976; Imbrie and Imbrie, 1980); nevertheless, cycles between 80 and $120 \mathrm{kyr}$ are not unusual (Huybers and Wunsch, 2005). During LGM the North American ice sheet was known to be dry (Bromwich et al., 2004); therefore, a constant LGM climate forcing beginning at an ice-free hemisphere takes longer to establish a fully grown North American ice sheet.

Owing to the focus on simplicity and numerical efficiency, the thermal coupling of the ice dynamics and basal melting are neglected. However, Calov and Marsiat (1998) showed that vertically integrated models yield results of comparable quality as thermomechanical models. They also conclude that the representation of surface mass balance is more important to simulate the last glacial cycle than the accurate description of ice dynamics. Nevertheless, Johnson and Fastook (2002) state that basal melting can have a dramatic ef- 
fect on the glaciation cycle. It is theoretically possible to approximate melting at the bottom of the ice sheet by a function based on accumulation rate, temperature, and geothermal heat flux. However, this could be the subject of future model development.

An additional concession to the numerical efficiency is the use of a local isostasy model instead of the common "elastic lithosphere, relaxing asthenosphere" (ELRA) model that takes into account non-local effects of the ice load (Le Meur and Huybrechts, 1996). Test simulations with the ELRA bedrock model are qualitatively similar to the results shown here, which is expected as the effect of a non-local lithosphere is mostly limited to small ice caps (Greve and Blatter, 2009). This makes it difficult to justify the computational overhead of the ELRA model, because due to the influence of remote grid locations, the local deformation of each grid location must be calculated from the ice load of about 600 neighboring boxes. This adds significant overhead to the comparatively lightweight ice dynamics, so that it runs approximately 100 times slower.

In long simulations we find multiple equilibria in ice volume, as evidenced by the hysteresis. A global temperature offset is applied to the $\mathrm{LGM}_{\mathrm{bs}}$ forcing. Starting at $+5^{\circ} \mathrm{C}$, approximately the difference between the simulated LGM and preindustrial climates in CCSM4 in the ice sheet model domain, the offset linearly decreases to $-5^{\circ} \mathrm{C}$ over the course of 2.5 million years. The very slow transient temperature change ensures that the simulated ice sheet remains in continuous quasi-equilibrium. Subsequently, temperature is increased slowly back to $+5^{\circ} \mathrm{C}$. Both the North American and Eurasian ice sheets are found to have at least two stable states over almost the entire temperature offset range.

Ice volume increases and decreases abruptly at several points on the temperature scale. As soon as temperatures are low enough for the local mass balance to become positive, the ice sheet quickly grows to higher, colder elevations and thereby stabilizes itself. This mechanism is consistent with similar simulations of the Cenozoic Antarctic ice sheet (Pollard and DeConto, 2005). Importantly, the individual jumps in ice volume depend on the local mass balance and the ice sheet geometry alone, which are both closely related to the bed topography. Variations in the model parameters play a secondary role as they may shift these glaciation and deglaciation events on the temperature scale but do not affect their existence or individual height.

Our hysteresis experiments are similar to simulations by Abe-Ouchi et al. (2013), although they employed more comprehensive representations for both climate variations and ice sheet dynamics and consequentially cannot continuously vary temperature offsets. We confirm that the hysteresis of the North American ice sheet is located at warmer temperature offsets than the hysteresis of the Eurasian ice sheet. Also, the retreating North American ice sheet is most sensitive to temperature increase when its volume is between 120 and $50 \mathrm{~m}$ s.l.e. Disagreement is found for the Eurasian ice sheet, as our model does not find a rapid retreat for rising temperatures. The simulated volume is generally lower here. This is likely due to the inadequate representation of marine ice sheets in our model.

The insufficient glaciation over Northern Europe shelf seas and the correct LGM ice volume over Eurasia may be recovered if the model is initialized with an ice-covered state like on the descending branch of the hysteresis. Initialization with a large global ice volume and corresponding low sea level allows ice to cover shelf seas and to grow thicker and more stable. However, the simple hysteresis initialization yields an ice volume of $45 \mathrm{~m}$ s.l.e. for the Eurasian ice sheet, considerably more than the $13-25 \mathrm{~m}$ s.l.e. in reconstructions (Clark and Mix, 2002). Note that this effect somewhat undermines the ensemble optimization that uses the LGM total ice volume as a target but initializes all simulations without ice.

Transient simulations from different starting points on both branches of the hysteresis highlight how this concept of ice sheet dynamics is robust and where it is incomplete. Rapid warming, similar to the warming rates ending the Last Glacial Maximum, generally does not lead to a new equilibrium on the hysteresis but produces a new equilibrium with a geographic distribution of ice that does not correspond to either of the two branches of the hysteresis. This is the result of the nonlinear response of the bedrock and its interaction with the surface mass balance, in its essence described by Oerlemans (1981b). To extend the present study, future versions of our efficient ice sheet model could be used to systematically explore and quantify the effect of different mechanisms on the stability of glacial ice sheets on a grid point level.

\section{Conclusions and outlook}

Ice sheet models of reduced complexity may complement comprehensive models of ice dynamics and thus close the gap that exists for climate simulations over many glacial cycles and over the next centuries to millennia. Their computational efficiency enables research questions that are not primarily concerned with the detailed stress balance inside the ice but rather benefit from a more detailed representation of the surface mass balance, a better coupling with the climate system, probabilistic analyses based on multiple simulations and parameter perturbations, or extremely long integration times. Several of these points arguably apply to the uncertainties and remaining questions related to the succession of ice ages over the last million years. The simulations of the Eemian interglacial are one recent example. Although different studies have used models with a similar threedimensional representation of ice dynamics, in some cases even the same model, the simulations of the Eemian minimum ice volume over Greenland diverge widely (Fig. 5.16 in Masson-Delmotte et al., 2013), probably due to the different representations of the climate forcing and the surface 
mass and energy balances (Robinson et al., 2011; Born and Nisancioglu, 2012; Quiquet et al., 2013; Stone et al., 2013).

We conclude that our model achieves a reasonable agreement for the ice distribution and volume of the Last Glacial Maximum and today in spite of its simplicity. Future simulations will benefit from a comprehensive surface mass and energy balance model (Greuell and Konzelmann, 1994; Reijmer and Hock, 2008; van den Berg et al., 2008; de Boer et al., 2013) that is currently being adapted for use on very long timescales. This will allow a fully bidirectional coupling of the ice sheet model with the Bern3D climate model (Ritz et al., 2011).

Investigations of climate change on orbital timescales have in the past been limited by computational constraints to statistical (Raymo and Nisancioglu, 2003; Huybers, 2006) or conceptual models (Paillard, 1998). With the increase in computational resources, coupled, physics-based ice sheetclimate models may be used to address this problem (Ganopolski and Calov, 2011; Stap et al., 2014). The present study contributes to this effort, taking a different approach than these previous studies.

Acknowledgements. A. Born acknowledges financial support from the European Commission through the Marie Curie Intra-European Fellowship ECLIPS (PIEF-GA-2011-300544). T. F. Stocker received support from the Swiss National Science Foundation. Climate forcing data were kindly provided by Niklaus Merz. Bas de Boer and the anonymous reviewer are gratefully acknowledged for their thoughtful comments.

Edited by: H. A. Dijkstra

\section{References}

Abe-Ouchi, A., Saito, F., Kawamura, K., Raymo, M. E., Okuno, J., Takahashi, K., and Blatter, H.: Insolation-driven 100,000-year glacial cycles and hysteresis of ice-sheet volume, Nature, 500, 190-193, doi:10.1038/nature12374, 2013.

Amante, C. and Eakins, B. W.: ETOPO1 1 arc-minute global relief model: procedures, data sources and analysis, US Department of Commerce, National Oceanic and Atmospheric Administration, National Environmental Satellite, Data, and Information Service, National Geophysical Data Center, Marine Geology and Geophysics Division, doi:10.7289/V5C8276M, 2009.

Arakawa, A. and Lamb, V. R.: Computational design of the basic dynamical processes of the UCLA general circulation model, Methods in Computational Physics: Advances in Research and Applications, 17, 173-265, 1977.

Archer, D., Winguth, A., Lea, D., and Mahowald, N.: What caused the glacial/interglacial atmospheric $\mathrm{pCO}_{2}$ cycles?, Rev. Geophys., 38, 159-189, doi:10.1029/1999RG000066, 2000.

Austermann, J., Mitrovica, J. X., Latychev, K., and Milne, G. A.: Barbados-based estimate of ice volume at Last Glacial Maximum affected by subducted plate, Nat. Geosci., 6, 553-557, doi:10.1038/ngeo1859, 2013.
Bamber, J. L., Griggs, J. A., Hurkmans, R. T. W. L., Dowdeswell, J. A., Gogineni, S. P., Howat, I., Mouginot, J., Paden, J., Palmer, S., Rignot, E., and Steinhage, D.: A new bed elevation dataset for Greenland, The Cryosphere, 7, 499-510, doi:10.5194/tc-7499-2013, 2013.

Berger, A.: Long-term variations of caloric insolation resulting from the Earth's orbital elements, Quaternary Res., 9, 139-167, 1978.

Bintanja, R. and van de Wal, R. S. W.: North American ice-sheet dynamics and the onset of 100,000-year glacial cycles, Nature, 454, 869-872, doi:10.1038/nature07158, 2008.

Bonelli, S., Charbit, S., Kageyama, M., Woillez, M.-N., Ramstein, G., Dumas, C., and Quiquet, A.: Investigating the evolution of major Northern Hemisphere ice sheets during the last glacialinterglacial cycle, Clim. Past, 5, 329-345, doi:10.5194/cp-5-3292009, 2009.

Born, A. and Nisancioglu, K. H.: Melting of Northern Greenland during the last interglaciation, The Cryosphere, 6, 1239-1250, doi:10.5194/tc-6-1239-2012, 2012.

Born, A., Kageyama, M., and Nisancioglu, K. H.: Warm Nordic Seas delayed glacial inception in Scandinavia, Clim. Past, 6, 817-826, doi:10.5194/cp-6-817-2010, 2010.

Braithwaite, R. J.: Positive degree-day factors for ablation on the Greenland ice sheet studied by energy-balance modelling, J. Glaciol., 41, 153-160, 1995.

Bromwich, D. H., Toracinta, E. R., Wei, H., Oglesby, R. J., Fastook, J. L., and Hughes, T. J.: Polar MM5 Simulations of the Winter Climate of the Laurentide Ice Sheet at the LGM* J. Climate, 17, 3415-3433, 2004.

Budd, W. F. and Smith, I. N.: The growth and retreat of ice sheets in response to orbital radiation changes, in: Sea level, ice, and climatic change, Proceedings of the Canberra Symposium, IAHS Publication, 131, 369-409, 1979.

Buizert, C., Gkinis, V., Severinghaus, J. P., He, F., Lecavalier, B. S., Kindler, P., Leuenberger, M., Carlson, A. E., Vinther, B. Masson-Delmotte, V., White, J. W. C., Liu, Z., Otto-Bliesner, B., and Brook, E. J.: Greenland temperature response to climate forcing during the last deglaciation, Science, 345, 1177-1180, doi:10.1126/science.1254961, 2014.

Calov, R. and Marsiat, I.: Simulations of the Northern Hemisphere through the last glacial-interglacial cycle with a vertically integrated and a three-dimensional thermomechanical ice-sheet model coupled to a climate model, Ann. Glaciol., 27, 169-176, 1998.

Cess, R. D., Potter, G. L., Zhang, M.-H., Blanchet, J.-P., Chalita, S., Colman, R., Dazlich, D. A., Genio, A. D. D., Dymnikov, V., Galin, V., Jerrett, D., Keup, E., Lacis, A. A., Le Treut, H., Liang, X.-Z., Mahfouf, J.-F., Mcavaney, B. J., Meleshko, V. P., Mitchell, J. F. B., Morcrette, J.-J., Norris, P. M., Randall, D. A., Rikus, L., Roeckner, E., Royer, J.-F., Schlese, U., Sheinin, D. A., Slingo, J. M., Sokolov, A. S., Taylor, K. E., Washington, W. M., Wetherald, R. T., and Yagai, I.: Interpretation of Snow-Climate Feedback as Produced by 17 General Circulation Models, Science, 253, 888-892, doi:10.1126/science.253.5022.888, 1991.

Charbit, S., Ritz, C., Philippon, G., Peyaud, V., and Kageyama, M.: Numerical reconstructions of the Northern Hemisphere ice sheets through the last glacial-interglacial cycle, Clim. Past, 3, 15-37, doi:10.5194/cp-3-15-2007, 2007.

Charbit, S., Dumas, C., Kageyama, M., Roche, D. M., and Ritz, C.: Influence of ablation-related processes in the build-up of sim- 
ulated Northern Hemisphere ice sheets during the last glacial cycle, The Cryosphere, 7, 681-698, doi:10.5194/tc-7-681-2013, 2013.

Clark, P. U. and Mix, A. C.: Ice sheets and sea level of the Last Glacial Maximum, Quaternary Sci. Rev., 21, 1-7, doi:10.1016/S0277-3791(01)00118-4, 2002.

Clark, P. U., Dyke, A. S., Shakun, J. D., Carlson, A. E., Clark, J., Wohlfarth, B., Mitrovica, J. X., Hostetler, S. W., and McCabe, A. M.: The Last Glacial Maximum, Science, 325, 710714, doi:10.1126/science.1172873, 2009.

Collins, W. D., Bitz, C. M., Blackmon, M. L., Bonan, G. B., Bretherton, C. S., Carton, J. A., Chang, P., Doney, S. C., Hack, J. J., Henderson, T. B., Kiehl, J. T., Large, W. G., McKenna, D. S., Santer, B. D., and Smith, R. D.: The Community Climate System Model version 3 (CCSM3), J. Climate, 19, doi:10.1175/JCLI3761.1, 2006.

de Boer, B., van de Wal, R., Lourens, L., Bintanja, R., and Reerink, T.: A continuous simulation of global ice volume over the past 1 million years with 3-D ice-sheet models, Clim. Dynam., 41, 1365-1384, doi:10.1007/s00382-012-1562-2, 2013.

Dee, D. P., Uppala, S. M., Simmons, A. J., Berrisford, P., Poli, P., Kobayashi, S., Andrae, U., Balmaseda, M. A., Balsamo, G., Bauer, P., Bechtold, P., Beljaars, A. C. M., van de Berg, L., Bidlot, J., Bormann, N., Delsol, C., Dragani, R., Fuentes, M., Geer, A. J., Haimberger, L., Healy, S. B., Hersbach, H., Hólm, E. V., Isaksen, L., Kållberg, P., Köhler, M., Matricardi, M., McNally, A. P., Monge-Sanz, B. M., Morcrette, J.-J., Park, B.-K., Peubey, C., de Rosnay, P., Tavolato, C., Thépaut, J.-N., and Vitart, F.: The ERA-Interim reanalysis: configuration and performance of the data assimilation system, Q. J. Roy. Meteor. Soc., 137, 553-597, doi:10.1002/qj.828, 2011.

Denton, G. H.: The last great ice sheets, John Wiley \& Sons, 484 pp., 1981.

Dixon, E. J.: Human colonization of the Americas: timing, technology and process, Quaternary Sci. Rev., 20, 277-299, doi:10.1016/S0277-3791(00)00116-5, 2001.

Dupont, T. and Alley, R.: Assessment of the importance of iceshelf buttressing to ice-sheet flow, Geophys. Res. Lett., 32, 1-4, doi:10.1029/2004GL022024, 2005.

Fischer, H., Schmitt, J., Lüthi, D., Stocker, T. F., Tschumi, T., Parekh, P., Joos, F., Köhler, P., Völker, C., Gersonde, R., Barbante, C., Le Floch, M., Raynaud, D., and Wolff, E.: The role of Southern Ocean processes in orbital and millennial $\mathrm{CO}_{2}$ variations - A synthesis, Quaternary Sci. Rev., 29, 193-205, doi:10.1016/j.quascirev.2009.06.007, 2010.

Fisher, D. A. and Koerner, R. M.: On the Special Rheological Properties of Ancient Microparticle-Laden Northern Hemisphere Ice As Derived From Bore-Hole and Core Measurements, J. Glaciol., 32, 501-510, 1986.

Forster, P.: Ice Ages and the mitochondrial DNA chronology of human dispersals: a review, Philos. T. Roy. Soc. B, 359, 255-264, 2004.

Gallée, H., Van Yperselb, J., Fichefet, T., Marsiat, I., Tricot, C., and Berger, A.: Simulation of the last glacial cycle by a coupled, sectorially averaged climate-ice sheet model: 2 . Response to insolation and $\mathrm{CO}_{2}$ variations, J. Geophys. Res., 97, 15713-15740, 1992.
Ganopolski, A. and Calov, R.: The role of orbital forcing, carbon dioxide and regolith in $100 \mathrm{kyr}$ glacial cycles, Clim. Past, 7, 1415-1425, doi:10.5194/cp-7-1415-2011, 2011.

Gent, P. R., Danabasoglu, G., Donner, L., Holland, M., Hunke, E., Jayne, S., Lawrence, D., Neale, R., Rasch, P., Vertenstein, M., Worley, P., Yang, Z.-L., and Zhang, M.: The Community Climate System Model version 4, J. Climate, 24, 4973-4991, 2011.

Gildor, H. and Tziperman, E.: A sea ice climate switch mechanism for the 100-kyr glacial cycles, J. Geophys. Res., 106, 9117-9133, 2001.

Glen, J. W.: The Creep of Polycrystalline Ice, P. Roy. Soc. A-Math. Phy., 228, 519-538, 1955.

Gregoire, L. J., Payne, A. J., and Valdes, P. J.: Deglacial rapid sea level rises caused by ice-sheet saddle collapses, Nature, 487, 219-222, doi:10.1038/nature11257, 2012.

Greuell, W. and Konzelmann, T.: Numerical modelling of the energy balance and the englacial temperature of the Greenland Ice Sheet. Calculations for the ETH-Camp location (West Greenland, 1155 ma.s.1.), Global Planet. Change, 9, 91-114, doi:10.1016/0921-8181(94)90010-8, 1994.

Greve, R.: A continuum-mechanical formulation for shallow polythermal ice sheets, Philos. T. Roy. Soc. A, 355, 921-974, doi:10.1098/rsta.1997.0050, 1997.

Greve, R. and Blatter, H.: Dynamics of ice sheets and glaciers, Springer Verlag, Berlin Heidelberg New York, doi:10.1007/9783-642-03415-2, 2009.

Hays, J. D., Imbrie, J., and Shackleton, N. J.: Variations in the Earth's Orbit: Pacemaker of the Ice Ages, Science, 194, 1121$1132,1976$.

Heinemann, M., Timmermann, A., Elison Timm, O., Saito, F., and Abe-Ouchi, A.: Deglacial ice sheet meltdown: orbital pacemaking and $\mathrm{CO}_{2}$ effects, Clim. Past, 10, 1567-1579, doi:10.5194/cp10-1567-2014, 2014.

Herrington, A. R. and Poulsen, C. J.: Terminating the Last Interglacial: the role of ice sheet-climate feedbacks in a GCM asynchronously coupled to an Ice Sheet Model, J. Climate, 25, 18711882, 2011.

Hofer, D., Raible, C., Merz, N., Dehnert, A., and Kuhlemann, J.: Simulated winter circulation types in the North Atlantic and European region for preindustrial and glacial conditions, Geophys. Res. Lett., 39, 39, 1-5, doi:10.1029/2012GL052296, 2012.

Hutter, K.: Theoretical glaciology: material science of ice and the mechanics of glaciers and ice sheets, Springer, vol. 1, 510 pp., 1983.

Huybers, P.: Early Pleistocene Glacial Cycles and the Integrated Summer Insolation Forcing, Science, 313, 508-511, 2006.

Huybers, P. and Wunsch, C.: Obliquity pacing of the late Pleistocene glacial terminations, Nature, 434, 491-494, 2005.

Huybrechts, P.: Sea-level changes at the LGM from ice-dynamic reconstructions of the Greenland and Antarctic ice sheets during the glacial cycles, Quaternary Sci. Rev., 21, 203-231, doi:10.1016/S0277-3791(01)00082-8, 2002.

Huybrechts, P. and de Wolde, J.: The dynamic response of the Greenland and Antarctic ice sheets to multiple-century climatic warming, J. Climate, 12, 2169-2188, 1999.

Huybrechts, P. and T'siobbel, S.: Thermomechanical modelling of northern hemisphere ice sheets with a two-level mass-balance parameterisation, Ann. Glaciol., 21, 111-116, 1995. 
Huybrechts, P., Payne, T., and Intercomparison Group EISMINT: The EISMINT benchmarks for testing ice-sheet models, Ann. Glaciol., 23, 1-12, doi:10.013/epic.12063, 1996.

Imbrie, J. and Imbrie, J. Z.: Modeling the climatic response to orbital variations, Science, 207, 943-953, 1980.

Johnson, J. and Fastook, J. L.: Northern Hemisphere glaciation and its sensitivity to basal melt water, Quatern. Int., 95-96, 65-74, doi:10.1016/S1040-6182(02)00028-9, 2002.

Kleman, J., Fastook, J., Ebert, K., Nilsson, J., and Caballero, R.: Pre-LGM Northern Hemisphere ice sheet topography, Clim. Past, 9, 2365-2378, doi:10.5194/cp-9-2365-2013, 2013.

Lambeck, K., Rouby, H., Purcell, A., Sun, Y., and Sambridge, M.: Sea level and global ice volumes from the Last Glacial Maximum to the Holocene, P. Natl. Acad. Sci. USA, 111, 15296-15303, doi:10.1073/pnas.1411762111, 2014.

Le Meur, E. L. and Huybrechts, P.: A comparison of different ways of dealing with isostasy: examples from modeling the Antarctic ice sheet during the last glacial cycle, Ann. Glaciol., 23, 309317, doi:10.013/epic.12717, 1996.

Li, C. and Battisti, D. S.: Reduced Atlantic storminess during last glacial maximum: Evidence from a coupled climate model, J. Climate, 21, 3561-3579, doi:10.1175/2007JCLI2166.1, 2008.

Liakka, J., Löfverström, M., and Colleoni, F.: The impact of the North American ice sheet on the evolution of the Eurasian ice sheet during the last glacial cycle, Clim. Past Discuss., 11, 52035241, doi:10.5194/cpd-11-5203-2015, 2015.

Lisiecki, L. E. and Raymo, M. E.: A Pliocene-Pleistocene stack of 57 globally distributed benthic $\delta^{18} \mathrm{O}$ records, Paleoceanography, 20, doi:10.1029/2004PA001071, 2005.

Loulergue, L., Schilt, A., Spahni, R., Masson-Delmotte, V., Blunier, T., Lemieux, B., Barnola, J.-M., Raynaud, D., Stocker, T. F., and Chappellaz, J.: Orbital and millennial-scale features of atmospheric $\mathrm{CH}_{4}$ over the past 800,000 years, Nature, 453, 383-386, 2008.

Lüthi, D., Le Floch, M., Bereiter, B., Blunier, T., Barnola, J.-M., Siegenthaler, U., Raynaud, D., Jouzel, J., Fischer, H., Kawamura, K., and Stocker, T. F.: High-resolution carbon dioxide concentration record 650,000-800,000 years before present, Nature, 453, 379-382, 2008.

Marshall, S. J., Tarasov, L., Clarke, G. K. C., and Peltier, W. R.: Glaciological reconstruction of the Laurentide Ice Sheet: physical processes and modelling challenges, Can. J. Earth Sci., 37, 769-793, 2000.

Masson-Delmotte, V., Schulz, M., Abe-Ouchi, A., Beer, J., Ganopolski, A., González Rouco, J. F., Jansen, E., Lambeck, K., Luterbacher, J., Naish, T., Osborn, T., Otto-Bliesner, B., Quinn, T., Ramesh, R., Rojas, M., Shao, X., and Timmermann, A.: Information from Paleoclimate Archives, in: Climate Change 2013: The Physical Science Basis, Contribution of Working Group I to the Fifth Assessment Report of the Intergovernmental Panel on Climate Change, edited by: Stocker, T.'F., Qin, D., Plattner, G.K., Tignor, M., Allen, S. K., Boschung, J., Nauels, A., Xia, Y., Bex, V., and Midgley, P. M., Cambridge University Press, Cambridge, UK and New York, NY, USA, 2013.

Merz, N., Raible, C. C., Fischer, H., Varma, V., Prange, M., and Stocker, T. F.: Greenland accumulation and its connection to the large-scale atmospheric circulation in ERA-Interim and paleoclimate simulations, Clim. Past, 9, 2433-2450, doi:10.5194/cp9-2433-2013, 2013.
Merz, N., Born, A., Raible, C. C., Fischer, H., and Stocker, T. F.: Dependence of Eemian Greenland temperature reconstructions on the ice sheet topography, Clim. Past, 10, 1221-1238, doi:10.5194/cp-10-1221-2014, 2014a.

Merz, N., Gfeller, G., Born, A., Raible, C. C., Stocker, T. F., and Fischer, H.: Influence of ice sheet topography on Greenland precipitation during the Eemian interglacial, J. Geophys. Res.-Atmos., 119, 10749-10768, doi:10.1002/2014JD021940, 2014b.

Milankovitch, M.: Kanon der Erdbestrahlung und seine Anwendung auf das Eiszeitproblem, Royal Serbian Academy, 132, 633 pp., 1941.

Neale, R. B., Richter, J., Park, S., Lauritzen, P. H., Vavrus, S. J., Rasch, P. J., and Zhang, M.: The Mean Climate of the Community Atmosphere Model (CAM4) in Forced SST and Fully Coupled Experiments, J. Climate, 26, 5150-5168, doi:10.1175/JCLID-12-00236.1, 2013.

Neeman, B. U., Ohring, G., and Joseph, J. H.: The Milankovitch theory and climate sensitivity: 2. Interaction between the northern hemisphere ice sheets and the climate system, J. Geophys. Res., 93, 11175-11191, 1988.

Näslund, J., Rodhe, L., Fastook, J., and Holmlund, P.: New ways of studying ice sheet flow directions and glacial erosion by computer modelling - examples from Fennoscandia, Quaternary Sci. Rev., 22, 245-258, doi:10.1016/S0277-3791(02)00079-3, 2003.

Oerlemans, J.: Modeling of pleistocene European ice sheets: Some experiments with simple mass-balance parameterizations, Quaternary Res., 15, 77-85, doi:10.1016/0033-5894(81)90115-0, 1981a.

Oerlemans, J.: Some basic experiments with a vertically-integrated ice sheet model, Tellus, 33, 1-11, 1981b.

Oerlemans, J.: Glacial cycles and ice-sheet modelling, Climatic Change, 4, 353-374, doi:10.1007/BF02423468, 1982.

Paillard, D.: The timing of Pleistocene glaciations from a simple multiple-state climate model, Nature, 391, 378-381, doi:10.1038/34891, 1998.

Pausata, F. S. R., Li, C., Wettstein, J. J., Kageyama, M., and Nisancioglu, K. H.: The key role of topography in altering North Atlantic atmospheric circulation during the last glacial period, Clim. Past, 7, 1089-1101, doi:10.5194/cp-7-1089-2011, 2011.

Peltier, W., Argus, D., and Drummond, R.: Space geodesy constrains ice age terminal deglaciation: The global ICE-6G_C (VM5a) model, J. Geophys. Res.-Solid Earth, 120, 450-487, doi:10.1002/2014JB011176, 2015.

Peltier, W. R.: On eustatic sea level history: Last Glacial Maximum to Holocene, Quaternary Sci. Rev., 21, 377-396, doi:10.1016/S0277-3791(01)00084-1, 2002.

Peltier, W. R.: Global glacial isostasy and the surface of the ice-age Earth: The ICE-5G (VM2) model and GRACE, Annu. Rev. Earth Pl. Sc., 32, 111-149, doi:10.1146/annurev.earth.32.082503.144359, 2004.

Plummer, M. A. and Phillips, F. M.: A 2-D numerical model of snow/ice energy balance and ice flow for paleoclimatic interpretation of glacial geomorphic features, Quaternary Sci. Rev., 22, 1389-1406, doi:10.1016/S0277-3791(03)00081-7, 2003.

Pollard, D. and DeConto, R. M.: Hysteresis in Cenozoic Antarctic ice-sheet variations, Global Planet. Change, 45, 9-21, 2005.

Quiquet, A., Ritz, C., Punge, H. J., and Salas y Mélia, D.: Greenland ice sheet contribution to sea level rise during the last interglacial period: a modelling study driven and constrained by ice 
core data, Clim. Past, 9, 353-366, doi:10.5194/cp-9-353-2013, 2013.

Raymo, M. E. and Nisancioglu, K.: The 41 kyr world: Milankovitch's other unsolved mystery, Paleoceanography, 18, 1011, doi:10.1029/2002PA000791, 2003.

Reeh, N.: Parameterization of melt rate and surface temperature on the Greenland Ice Sheet, Polarforschung, 59, 113-128, 1991.

Reijmer, C. H. and Hock, R.: Internal accumulation on Storglaciären, Sweden, in a multi-layer snow model coupled to a distributed energy-and mass-balance model, J. Glaciol., 54, 61-72, 2008.

Ritz, C., Fabre, A., and Letréguilly, A.: Sensitivity of a Greenland ice sheet model to ice flow and ablation parameters: consequences for the evolution through the last climatic cycle, Clim. Dynam., 13, 11-24, 1997.

Ritz, S. P., Stocker, T. F., and Joos, F.: A coupled dynamical oceanenergy balance atmosphere model for paleoclimate studies, J. Climate, 24, 349-375, doi:10.1175/2010JCLI3351.1, 2011.

Robinson, A., Calov, R., and Ganopolski, A.: Greenland ice sheet model parameters constrained using simulations of the Eemian Interglacial, Clim. Past, 7, 381-396, doi:10.5194/cp-7-381-2011, 2011.

Roe, G. H.: Modeling precipitation over ice sheets: an assessment using Greenland, J. Glaciol., 48, 70-80, 2002.

Roe, G. H. and Lindzen, R. S.: The mutual interaction between continental-scale ice sheets and atmospheric stationary waves, J. Climate, 14, 1450-1465, 2001.

Schilt, A., Baumgartner, M., Blunier, T., Schwander, J., Spahni, R., Fischer, H., and Stocker, T. F.: Glacial-interglacial and millennial-scale variations in the atmospheric nitrous oxide concentration during the last 800,000 years, Quaternary Sci. Rev., 29, 182-192, doi:10.1016/j.quascirev.2009.03.011, 2010.

Siegert, M. J. and Marsiat, I.: Numerical reconstructions of LGM climate across the Eurasian Arctic, Quaternary Sci. Rev., 20, 1595-1605, 2001.

Siegert, M. J., Dowdeswell, J. A., and Melles, M.: Late Weichselian Glaciation of the Russian High Arctic, Quaternary Res., 52, 273285, doi:10.1006/qres.1999.2082, 1999.

Smith, G., Mysak, L., Wang, Z., and Blatter, H.: McGill paleoclimate model ice sheet sensitivity to ice flow rate and discharge parameters, Clim. Dynam., 20, 315-325, doi:10.1007/s00382-0020273-5, 2003.

Spahni, R., Joos, F., Stocker, B. D., Steinacher, M., and Yu, Z. C.: Transient simulations of the carbon and nitrogen dynamics in northern peatlands: from the Last Glacial Maximum to the 21st century, Clim. Past, 9, 1287-1308, doi:10.5194/cp-9-1287-2013, 2013.

Stap, L. B., van de Wal, R. S. W., de Boer, B., Bintanja, R., and Lourens, L. J.: Interaction of ice sheets and climate during the past 800000 years, Clim. Past, 10, 2135-2152, doi:10.5194/cp10-2135-2014, 2014.

Stocker, T. F.: Ocean Circulation and Climate: A 21st Century Perspective, chap. The ocean as a component of the climate system, 3-30, edited by: Siedler, G., Griffies, S. M., Gould, J., and Church, J. A., Academic Press, Amsterdam, 3-30, 2013.
Stokes, C. R., Tarasov, L., and Dyke, A. S.: Dynamics of the North American Ice Sheet Complex during its inception and build-up to the Last Glacial Maximum, Quaternary Sci. Rev., 50, 86-104, doi:10.1016/j.quascirev.2012.07.009, 2012.

Stone, E. J., Lunt, D. J., Annan, J., and Hargreaves, J.: Quantification of the Greenland ice sheet contribution to Last Interglacial sea level rise, Clim. Past, 9, 621-639, doi:10.5194/cp-9-6212013, 2013.

Straneo, F. and Heimbach, P.: North Atlantic warming and the retreat of Greenland's outlet glaciers, Nature, 504, 36-43, doi:10.1038/nature12854, 2013.

Svendsen, J. I., Alexanderson, H., Astakhov, V. I., Demidov, I., Dowdeswell, J. A., Funder, S., Gataullin, V., Henriksen, M., Hjort, C., Houmark-Nielsen, M., Hubberten, H. W., Ingólfsson, Ó., Jakobsson, M., Kjar, K. H., Larsen, E., Lokrantz, H., Lunkka, J. P., Lyså, A., Mangerud, J., Matiouchkov, A., Murray, A., Möller, P., Niessen, F., Nikolskaya, O., Polyak, L., Saarnisto, M., Siegert, C., Siegert, M. J., Spielhagen, R. F., and Stein, R.: Late Quaternary ice sheet history of northern Eurasia, Quaternary Sci. Rev., 23, 1229-1271, 2004.

Tarasov, L. and Peltier, W. R.: Impact of thermomechanical ice sheet coupling on a model of the $100 \mathrm{kyr}$ ice age cycle, J. Geophys. Res., 104, 9517-9545, 1999.

van den Berg, J., van de Wal, R., and Oerlemans, H.: A mass balance model for the Eurasian Ice Sheet for the last 120,000 years, Global Planet. Change, 61, 194-208, doi:10.1016/j.gloplacha.2007.08.015, 2008.

van den Broeke, M., Bamber, J., Ettema, J., Rignot, E., Schrama, E., van de Berg, W. J., van Meijgaard, E., Velicogna, I., and Wouters, B.: Partitioning Recent Greenland Mass Loss, Science, 326, 984986, 2009.

Verbitsky, M. Y. and Oglesby, R. J.: The effect of atmospheric carbon dioxide concentration on continental glaciation of the Northern Hemisphere, J. Geophys. Res., 97, 5895-5909, 1992.

Vizcaino, M., Mikolajewicz, U., Gröger, M., Maier-Reimer, E., Schurgers, G., and Winguth, A.: Long-term ice sheet-climate interactions under anthropogenic greenhouse forcing simulated with a complex Earth System Model, Clim. Dynam., 31, 665690, doi:10.1007/s00382-008-0369-7, 2008.

Waelbroeck, C., Labeyrie, L., Michel, E., Duplessy, J. C., McManus, J. F., Lambeck, K., Balbon, E., and Labracherie, M.: Sealevel and deep water temperature changes derived from benthic foraminifera isotopic records, Quaternary Sci. Rev., 21, 295-305, 2002.

Xu-Ri and Prentice, I. C.: Terrestrial nitrogen cycle simulation with a dynamic global vegetation model, Glob. Change Biol., 14, 1745-1764, doi:10.1111/j.1365-2486.2008.01625.x, 2008.

Ziemen, F., Rodehacke, C., and Mikolajewicz, U.: Coupled ice sheet-climate modeling under glacial and pre-industrial boundary conditions, Clim. Past, 10, 1817-1836, doi:10.5194/cp-101817-2014, 2014.

Zweck, C. and Huybrechts, P.: Modeling of the northern hemisphere ice sheets during the last glacial cycle and glaciological sensitivity, J. Geophys. Res., 110, D07103, doi:10.1029/2004JD005489, 2005. 